Available online on www.ijpqa.com

International Journal of Pharmaceutical Quality Assurance 2018; 9(3); 260-266

doi: $\underline{10.25258 / \text { ijpqa.v9i3.13657 }}$

Research Article

ISSN 09759506

\title{
Effectiveness of Fish Oil Containing Omega-3 in Improving Symptoms and Lung Function in Asthma Outpatient in Surabaya, Indonesia
}

\author{
Amelia Lorensia ${ }^{1 *}$, Mariana Wahyudi ${ }^{2}$, Nadia Aisah Mayzika ${ }^{3}$ \\ ${ }^{I}$ Departement of Clinical-Community Pharmacy, Faculty of Pharmacy, University of Surabaya (Universitas Surabaya \\ (UBAYA)), Surabaya \\ ${ }^{2}$ Departement of Purification and Molecular Biology, Faculty of Biotechnology, University of Surabaya (Universitas \\ Surabaya (UBAYA)), Surabaya \\ ${ }^{3}$ Postgraduate Student of Master of Pharmacy Science, Faculty of Pharmacy, University of Surabaya (Universitas \\ Surabaya (UBAYA)), Surabaya
}

Received: $25^{\text {th }}$ Apr, 18; Revised: $2^{\text {nd }}$ Aug, 18, Accepted: $25^{\text {th }}$ Aug, 18; Available Online: $25^{\text {th }}$ Sep, 2018

\begin{abstract}
Indonesia as a potential maritime country in fish production, can be processed into fish oil containing omega-3. Based on previous libraries, omega-3 fish oils can be used to improve asthma control and improve lung function. The effects of a drug are individualized depending on genetic and environmental factors. The aim of the study was to investigate the effect of fish oil containing omega-3 on improving asthma symptoms and improving lung function. The research method used is pre-post test design, using data collection technique with asthma control test questionnaire to see clinical symptoms of asthma and measure lung function with peak flow meter. Intervention given is a fish oil product with once daily doses, then follow up every week for 4 weeks. The subject of research is adult age. Pulmonary function data and asthma symptoms will be tested for normality with shapiro-wilk test and followed by anova one way. The research was conducted in 20162017 in Surabaya and the data obtained 28 respondents. At the control level of asthma and total ACT score $(\mathrm{P}<0.05)$ it can be concluded that there was significant difference between before and after omega-3 fish oil therapy for 4 weeks. In the improvement of lung function there is a significant improvement of lung function starting from before therapy until the increase every week until the 4 th week. Fish oil containing omega 3 for 4 weeks may decrease asthma symptoms in the asthma control level category and total ACT score. In addition, fish oil can also improve lung function significantly in every week.
\end{abstract}

Keywords: asthma, fish oil contains omega-3, asthma symptoms, lung function.

\section{INTRODUCTION}

Asthma is a heterogeneous disease in the form of chronic respiratory tract inflammation characterized by respiratory symptoms such as wheezing, shortness of breath, feeling depressed in the chest and cough. Despite the low level of fatality but the number of cases is quite common in the community. The World Health Organization (WHO) estimates that 100-150 million people worldwide suffer from asthma. Even this number is expected to continue to grow to reach 180,000 people every year ${ }^{1-2}$. Adverse effects of asthma include decreased quality of life, decreased productivity, school absenteeism, increased healthcare costs, hospital care risks and even death ${ }^{3}$. Increases in the prevalence of asthma in Asia such as Singapore, Taiwan, Japan or South Korea are also striking. The incidence of asthma has increased over fifteen years, both in developing and developed countries. In Indonesia, the prevalence of asthma is not known for certain, but it is estimated that $2-5 \%$ of Indonesia's population suffers from asthma. The Department of Health estimates that asthma is among the top 10 causes of illness and mortality in hospitals and an estimated $10 \%$ of Indonesia's 25 million people suffer from asthma. The prevalence of asthma in urban areas is generally higher than in rural areas, as urban lifestyle increases the risk of asthma. According to RISKESDAS (2013) asthma prevalence in Indonesia reached $4.5 \%$ with asthma prevalence in East Java 5.1\% ${ }^{4-}$ 5

In Indonesia, which is a maritime country, has great potential in fish production and even the government also launched GEMARIKAN in 2014, to popularize fish consumption. Fish has been known to be processed into fish oil containing high omega-3. Fish consumption can prevent asthma in adult patients. Research has shown that fish consumption at least once a month can reduce the risk of asthma ${ }^{6}$. In the meantime, several fish oilrelated studies, including omega-3s as Aprizayanti $(2011)^{7}$ and Santoso et al. (2013) ${ }^{8}$. Omega-3 has been used only as a supplement in helping the child's growth process, help lower cholesterol, heart disease. High intake of fish oil has protective effect against asthma and or allergies ${ }^{9}$. Omega-3 polyunsaturated fatty acids (n-3 PUFAs) consisting of eicosapentaenoic acid (EPA) and docosahexaenoic acid (DHA) are found primarily in

*Author for Correspondence: amelia.lorensia@gmail.com 
Table 1: Frequency Distribution of Respondent Characteristics.

\begin{tabular}{llll}
\hline Characteristics & & Number (n: 26) & Percentage (\%) \\
\hline Gender & Male & 7 & 27,00 \\
& Female & 19 & 73,00 \\
Age (years) & Youth end (17-25) & 25 & 96,15 \\
& Early adult (26-35) & 1 & 3,85 \\
& Late adult (36-45) & 0 & 0,00 \\
History of Asthma & Oral agonist beta-2 short acting & 8 & 21,05 \\
Treatment based on & Inhaled agonist beta-2 short acting & 10 & 26,31 \\
Global Initiative for & Oxygen & 1 & 2,63 \\
Asthma (2016) & Not taking any medication & 3 & 2,89 \\
& Oral corticosteroids (used only when symptoms & 1 & 11,53 \\
& worsen) & & \\
& Oral methylxanthine (used only when symptoms & 3 & \\
& worsen) & & \\
\end{tabular}

Table 2: Frequency Distribution Assessment of Asthma Symptoms Based on ACT.

\begin{tabular}{|c|c|c|c|}
\hline \multirow[t]{2}{*}{ Asthma Assessment Category } & & \multicolumn{2}{|c|}{ Number of Respondents } \\
\hline & & $\mathrm{ACT}_{0}$ & $\mathrm{ACT}_{4}$ \\
\hline Asthma Control Based on & Every now and then & 1 & 0 \\
\hline \multirow[t]{4}{*}{ Activity Limitations } & Too often & 0 & 0 \\
\hline & Often & 2 & 4 \\
\hline & Not too often & 14 & 16 \\
\hline & Never & 9 & 6 \\
\hline Asthma Control Based on & More than once a day & 0 & 0 \\
\hline Frequency of Shortness of & Once a day & 0 & 0 \\
\hline \multirow[t]{3}{*}{ Breath } & 3-6 times a week & 5 & 3 \\
\hline & Once or twice a week & 14 & 14 \\
\hline & Not a week at all & 7 & 9 \\
\hline Asthma Control Based on & 4 or more nights per week & 2 & 2 \\
\hline Symptoms Symptom Asthma & 2-3 nights per week & 3 & 1 \\
\hline \multirow[t]{3}{*}{ At Night or Morning } & once a week & 4 & 0 \\
\hline & Once or twice & 6 & 14 \\
\hline & not at all & 11 & 9 \\
\hline Asthma Control Based on & 3 or more per day & 1 & 0 \\
\hline Frequency of Asthma Drug & 1 or 2 times per day & 2 & 3 \\
\hline \multirow[t]{3}{*}{ Use } & 2 or 3 times per week & 4 & 5 \\
\hline & Once a week or less & 5 & 4 \\
\hline & not at all & 14 & 14 \\
\hline Asthma Control Based on & Not controlled at all & 8 & 3 \\
\hline \multirow[t]{4}{*}{ Asthma Control Level } & Less controlled & 6 & 5 \\
\hline & Simply controlled & 6 & 8 \\
\hline & Well controlled & 4 & 6 \\
\hline & Full controlled & 0 & 4 \\
\hline \multirow[t]{3}{*}{ ACT Total } & Uncontrolled (total value of ACT: $<19$ ) & 17 & 11 \\
\hline & Partially controlled (total value ACT: $20-24$ ) & 5 & 13 \\
\hline & Full controlled (total value ACT: 25 ) & 4 & 2 \\
\hline
\end{tabular}

fish oil. Epidemiological studies show that omega-3 has a protective effect against cardiovascular disease myocardial infarction or cerebral infarction, hypertension, and hyperlipidemia. In addition, omega-3 has beneficial effects on chronic inflammatory diseases including chronic obstructive pulmonary disease (COPD), asthma, rheumatoid arthritis, and inflammation of the intestine. Atopic sensitization and allergies can also be prevented with fish intake during pregnancy ${ }^{10}$.

In Indonesia has conducted several studies related to fish oil, which among others contain omega-3. Omega-3 is used as a supplement in helping the child's growth process, help lower cholesterol, heart disease $\mathrm{e}^{7,8,10,11,12}$. But there has been no research related to the effect of omega- 3 on the improvement of asthma in Indonesia. The antiinflammatory effect on omega-3 is due to the content of EPA which is a competitive substrate with arachidonate so it has the potential to reduce inflammation of the respiratory tract and bronchoconstriction. This has led to a new understanding over the last 30 years that fish oil deficiency can aggravate asthma ${ }^{13}$.

This study aims to determine the effect of omega-3 on the control of asthma in patients with asthma in Surabaya who 
Table 3: ACT Normality Assessment Test Group Intervention

\begin{tabular}{llll}
\hline Asthma Assessment Category & \multicolumn{2}{c}{ P value } \\
\cline { 2 - 4 } & $\mathrm{ACT}_{0}$ & $\mathrm{ACT}_{4}$ & Conclusion \\
\hline Activity Limitations & 0,00 & 0,00 & Distribution of data is not normal \\
Frequency of Shortness of Breath & 0,00 & 0,00 & Distribution of data is not normal \\
Asthma Symptoms At Night or Morning & 0,00 & 0,00 & Distribution of data is not normal \\
Frequency of Asthma Drug Use & 0,00 & 0,00 & Distribution of data is not normal \\
Level of asthma control & 0,001 & 0,044 & Distribution of data is not normal \\
ACT Total & 0,558 & 0,460 & Distribution of data is normal \\
\hline
\end{tabular}

$\mathrm{P}>0.05$ means normal distribution; $\mathrm{P}<0.05$ means the distribution is not normal

Table 4: Changes in ACT Value as Asthma Symptoms

\begin{tabular}{llll}
\hline Asthma Assessment Category & \multicolumn{2}{c}{ Number of Respondents } \\
\cline { 2 - 4 } & & Change the value of $\mathrm{ACT}_{0}$ to $\mathrm{ACT}_{4}$ \\
\cline { 2 - 4 } & $\mathrm{Up}$ & Constant & Down \\
\hline Activity Limitations & 5 & 15 & 2 \\
Frequency of Shortness of Breath & 6 & 18 & 3 \\
Asthma Symptoms At Night or Morning & 6 & 17 & 5 \\
Frequency of Asthma Drug Use & 4 & 17 & 1 \\
Level of asthma control & 16 & 9 & 5 \\
ACT Total & 15 & 6 & 5 \\
\hline
\end{tabular}

Table 5: ACT Differences Test Before and After Omega-3 Fish Oil Therapy.

\begin{tabular}{|c|c|c|c|c|c|}
\hline \multirow[t]{2}{*}{ Asthma Assessment Category } & \multicolumn{2}{|c|}{ Average } & \multicolumn{3}{|c|}{ Test the Difference } \\
\hline & $\mathrm{ACT}_{0}$ & $\mathrm{ACT}_{4}$ & $\mathrm{P}$ value & Type of Test Used & Conclusion \\
\hline Activity Limitations & 3,81 & 4,08 & 0,763 & Friedman Test & $\begin{array}{l}\text { There is no significant } \\
\text { difference }\end{array}$ \\
\hline $\begin{array}{l}\text { Frequency of Shortness of } \\
\text { Breath }\end{array}$ & 4,08 & 4,23 & 0,157 & Friedman Test & $\begin{array}{l}\text { There is no significant } \\
\text { difference }\end{array}$ \\
\hline $\begin{array}{l}\text { Asthma Symptoms At Night or } \\
\text { Morning }\end{array}$ & 3,81 & 4,04 & 0,317 & Friedman Test & $\begin{array}{l}\text { There is no significant } \\
\text { difference }\end{array}$ \\
\hline Frequency of Asthma Drug Use & 4,12 & 4,12 & 0,739 & Friedman Test & $\begin{array}{l}\text { There is no significant } \\
\text { difference }\end{array}$ \\
\hline Level of asthma control & 2,08 & 3,12 & 0,00 & Friedman Test & $\begin{array}{l}\text { There is a significant } \\
\text { difference }\end{array}$ \\
\hline ACT Total & 17,89 & 19,58 & 0,041 & Anova One Way & $\begin{array}{l}\text { There is a significant } \\
\text { difference }\end{array}$ \\
\hline
\end{tabular}

$\mathrm{P}>0.05$, Ho accepted means there is no significant difference

$\mathrm{P}<0.05$, Ho rejected means there is a significant difference

will be given fish oil. During this treatment asthma focuses on therapy with long-term synthetic drugs, which can cause problems such as: the use of aminophylline which is a drug with a narrow range of therapy so that the risk of causing side effects ${ }^{14,15,16}$, single use of long-acting beta-2 agonist that can aggravate Exacerbation of asthma ${ }^{17}$, or the use of inhaled corticosteroids that may cause oropharyngeal candidiasis and even lung infections ${ }^{1}$.

This study aims to determine the effect of fish oil containing omega-3 to improve asthma symptoms and improve lung function. Patients with a high level of education influence self evaluation so that it can affect the patient's asthma control level. This study uses research subjects with a minimum education level of high school with the hope that the level of asthma control is good, and is expected this study can also increase knowledge related to the influence of nutrition on asthma, in the role of pharmacist to support the handling of asthma by motivating patients to be obedient in treatment, Provide information, counseling, and education so that they better understand the treatment regimen provided so that patients can be more actively involved in their treatment which can improve their adherence to drug use. Treatment of asthma is a long-term treatment and adherence to medication and treatment is desirable. It is expected that good patient compliance will affect the number of drugs used less, fewer doses per day, the incidence of drug side effects is less common ${ }^{3}$.

\section{METHOD}

This research uses pre-post test design method. This study used data collection techniques with Asthma Control Test questionnaire to see clinical symptoms of asthma and measure lung function with peak flow meter tool. Each sample of the study was given fish oil. Intervention given is a fish oil products circulating in Indonesia. Fish oil is given to patients with once daily doses, then follow up every week for 4 weeks. Dosage of fish oil containing 
Tabel 6: Average PEF Value and Normality Test for Lung Function Data

\begin{tabular}{llllll}
\hline Group & $\begin{array}{l}\text { Average } \\
\text { (L/sec) }\end{array}$ & PEF & Value & \multicolumn{3}{c}{ Test Data Normality } & \\
\cline { 3 - 5 } & 217,96 & & Type of Test Used & P value & Conclusion \\
\hline PEF $_{0}$ & 273,15 & & Shapiro wilk & 0,002 & No normal \\
PEF $_{1}$ & 295,56 & & Shapiro wilk & 0,131 & Normal \\
PEF $_{2}$ & 298,89 & & Shapiro wilk & 0,109 & Normal \\
PEF $_{3}$ & 325,00 & & Shapiro wilk & 0,209 & Normal \\
PEF $_{4}$ & & Shapiro wilk & 0,089 & Normal \\
\hline
\end{tabular}

$\mathrm{P}>0.05$ means normal distribution; $\mathrm{P}<0.05$ means the distribution is not normal

omega-3 recommended by 1 gram to 5.4 gram per day ${ }^{18}$, then in this study selected fish oil with dose of 1.0 gram.

The independent variable of this research is fish oil. While the dependent variables of this study are symptoms of asthma and lung function, with controlled variables according to inclusion and exclusion criteria.

Symtoms of asthma: Symptoms of asthma were measured by using the Asthma Control Test (ACT) questionnaire. $\mathrm{ACT}$ is one of the specific instruments in assessing asthma control in patients with chronic asthma. Consisting of 5 questions that include activity limitation, shortness of breath, asthma symptoms at night, frequency of reliever drug use, and asthma control rate counted for 4 weeks. Each question is given a choice of 5- Likert ${ }^{1,19}$. Symptoms of asthma were measured 2 times, ie, at week 0 (before intervention) and at week 4 (after intervention). Initials to use:

$\mathrm{ACT}_{0}$ : The value of $\mathrm{ACT}$ at week 0 , ie before getting fish oil therapy contains omega-3

$\mathrm{ACT}_{4}$ : The value of ACT at week 4, ie after getting fish oil therapy containing omega-3 for 4 weeks (one month)

Lung function: Pulmonary function is measured from the Peak Expiratory Flow (PEF) value. PEF is the maximum ability to expel air in the lungs from the maximum inspiratory state through the mouth in liters per minute units measured by peak flow meter which is a simple and easy to apply tool ${ }^{1}$. Pulmonary function is measured 5 times, ie once before the intervention and 3 times During intervention (after 1 week, 2 week, and 3 week intervention), and after intervention. Initials to use:

$\mathrm{PEF}_{0}$ : PEF value at week 0 , ie before getting fish oil therapy contains omega-3

$\mathrm{PEF}_{1}$ : PEF value at week 1st, after getting fish oil therapy containing omega-3 for 1 week

$\mathrm{PEF}_{2}$ : The value of PEF at week 2nd, ie after getting fish oil therapy contains omega-3 for 2 weeks

$\mathrm{PEF}_{3}$ : PEF value at week $3 \mathrm{rd}$, ie after getting fish oil therapy containing omega-3 for 3 weeks

$\mathrm{PEF}_{4}$ : PEF value at week 4 th, ie after getting fish oil therapy containing omega- 3 for 4 weeks (one month)

The population of this study were adult asthma patients ( $>$ 18 years) in Surabaya. The sample (subject) of the study were adult asthma patients who were willing to engage in research and meet the requirements, namely: (1) no chronic diseases that can affect respiratory function (such as chronic respiratory illness, heart disease, chronic renal failure, etc.); (2) No smoking or consuming alcohol; and (3) not taking routine asthma medication.

Pulmonary function data and asthma symptoms will be tested the normality of data distribution by using shapiro- wilk test. If $p>0,05$ then it can be concluded that normal distribution data and then proceed with one way anova to know the improvement of lung function and clinical symptoms among respondents Before and after using fish oil.

\section{RESULT}

The research was conducted in 2016-2017 in Surabaya. The data used in this study were obtained through the asthma control test (ACT) questionnaire given at the beginning of the first week and the end of the 4th week, peak expiratory flow (PEF) measured weekly for 5 weeks. Based on the data obtained 28 respondents, but 2 people dropped out due to allergy to fish oil and resigned because out of town, then only 26 people who can follow the research.

\section{Characteristics of Respondents}

Respondents in this study were grouped by sex, age, and medical history. The number of respondents based on the characteristics of respondents includes age and gender. In the age category, the largest number is the final adolescent (17-25 years old) that is equal to $96.15 \%$ or a number of 25 people and the largest number of female respondents is $73 \%$ or 19 respondents from the total of 26 respondents. The largest number was in the respondents who used a group of agonist beta- 2 short inhalation work of $26.31 \%$ in step 1 (Table 1).

Improvement of Asthma Symptoms with Fish Oil Therapy Containing Omega-3

Characteristics of respondents can be seen in table 2 with the depiction of each category ACT. Most of the symptoms of respondent asthma in three categories, namely: based on activity limitations, frequency of shortness of breath, frequency of asthma drug use, showed no change. But in most asthma symptoms based on asthma symptoms appearing in the evening or morning shows a decrease from the point "not at all" to "once up to two times". While asthma symptoms based on the level of control of respondents asthma increased. Based on the total of the overall ACT score, it showed improvement of most respondents with uncontrolled asthma symptoms being partially controlled (Table 2).

Normality tests across all ACT categories show all data not normally distributed, except for the total ACT values showing normal distributed data (Table 3).

The change in the value of asthma symptoms was divided into 3, ie "up" (there was an increase in ACT values after 4 weeks of fish oil), "fixed" (no change in ACT values after 4 weeks of fish oil) and "down" There was a decrease in ACT value change after being given fish oil for 4 weeks). 
Table 7: Changes in PEF Value and Pef Value Differences Test Before and After Omega-3 Fish Oil Therapy.

\begin{tabular}{|c|c|c|c|c|c|c|}
\hline \multirow[t]{3}{*}{ Compared groups } & \multirow{2}{*}{\multicolumn{3}{|c|}{$\begin{array}{l}\text { Jumlah Responden } \\
\text { Changes in PEF Value }(\mathrm{L} / \mathrm{sec})\end{array}$}} & \multicolumn{3}{|c|}{ Uji Perbedaan } \\
\hline & & & & \multirow[t]{2}{*}{$\mathrm{P}$ value } & \multirow[t]{2}{*}{ Type of Test Used } & \multirow{2}{*}{ Conclusion } \\
\hline & Up & Constant & Down & & & \\
\hline $\mathrm{PEF}_{0}$ and $\mathrm{PEF}_{1}$ & 20 & 2 & 5 & 0,014 & Friedman Test & $\begin{array}{l}\text { There is a significant } \\
\text { difference }\end{array}$ \\
\hline $\mathrm{PEF}_{0}$ and $\mathrm{PEF}_{2}$ & 21 & 1 & 5 & 0,003 & Friedman Test & $\begin{array}{l}\text { There is a significant } \\
\text { difference }\end{array}$ \\
\hline $\mathrm{PEF}_{0}$ and $\mathrm{PEF}_{3}$ & 20 & 1 & 6 & 0,009 & Friedman Test & $\begin{array}{l}\text { There is a significant } \\
\text { difference }\end{array}$ \\
\hline $\mathrm{PEF}_{0}$ and $\mathrm{PEF}_{4}$ & 24 & 1 & 2 & 0,00 & Friedman Test & $\begin{array}{l}\text { There is a significant } \\
\text { difference }\end{array}$ \\
\hline $\mathrm{PEF}_{1}$ and $\mathrm{PEF}_{2}$ & 20 & 0 & 7 & 0,00 & Anova One Way & $\begin{array}{l}\text { There is a significant } \\
\text { difference }\end{array}$ \\
\hline $\mathrm{PEF}_{2}$ and $\mathrm{PEF}_{3}$ & 16 & 2 & 9 & 0,013 & Anova One Way & $\begin{array}{l}\text { There is a significant } \\
\text { difference }\end{array}$ \\
\hline $\mathrm{PEF}_{3}$ and $\mathrm{PEF}_{4}$ & 21 & 0 & 6 & 0,017 & Anova One Way & $\begin{array}{l}\text { There is a significant } \\
\text { difference }\end{array}$ \\
\hline
\end{tabular}

$\mathrm{P}>0.05 ;$ Ho rejected means there is no significant difference

$\mathrm{P}<0.05$; Ho accepted means there is a significant difference

From table 4, it can be concluded that most improvements in asthma symptoms are seen only in the asthma level control category, whereas other categories show a fixed value. However, when viewed from the total value of ACT, showed most respondents experienced improvement (Table 4).

Test the difference of asthma symptoms based on ACT value before and after fish oil therapy in table 5 . At the control level of asthma and total ACT value $(\mathrm{P}<0,05)$ it can be concluded that there was significant difference between before and after fish oil therapy containing omega-3 For 4 weeks (Table 5).

Improvement of Lung Function with Omega-3 Fish Oil Therapy

The Difference Test describes the average PEF score obtained once a week after the respondents get a fish oil intervention for 4 weeks. The largest number was in the intervention group at week 4 with an average of 325,00 (Table 6).

Based on the normality test from table 6 indicating that there is data showing abnormal distribution (PEF0 data), the difference test using Friedman Test (Table 7). Based on the difference test, it was concluded that there was a significant improvement on every week (Table 7).

\section{DISCUSSION}

Discussion of Asthma Symptoms Improvement

The results showed changes in ACT values that increased from uncontrolled conditions before treatment were then partially controlled after therapy. This is consistent with existing libraries that the omega-3 content of fish oil containing fatty acids has a beneficial effect on chronic inflammatory diseases including chronic obstructive pulmonary disease (COPD), asthma, rheumatoid arthritis, and inflammatory diseases ${ }^{18}$. Fish oils containing omega 3 comprising EPA and DHA suppress the production of arachidonic acid through the ALOX5 pathway. Arachidonic acid is a substrate for eicosanoid synthesis that produces an inflammatory mediator consisting of
CYS-LT, prostaglandin, and thromboxane. This mediator is involved in the bronchoconstriction process and improves the respiratory tract mucus in asthma patients. EPA-enriched fish oil can inhibit the competitive production of LTC4 with arachidonic acid that acts as an ALOX5 substrate. EPA can also suppress an allergic response to asthma by inhibiting arachidonic acid that produces leukotrienes. Leukotriene and prostaglandin E2 contribute to the formation of immunoglobulin E ( $\operatorname{IgE})$, an antibody that contributes to the occurrence of an allergic response. This is usually increased in patients with asthma $^{13}$. Although the respondents experienced an improvement in ACT scores, there were several factors that could affect the value of ACT, among others:

Gender and age: In table 1, shows the largest number of samples are women than men. In boys have a greater risk in infancy and this risk decreases as they mature. While in women have a risk of staying in childhood and adulthood. The prevalence of women is higher than men, but the reason for the difference is not clear. However, at birth, men's lung size is smaller than women but as adults are larger. The risk of asthma in boys decreases as they grow older. While in women, the influence of estrogen and progesterone hormones can cause high asthma risk in women during and after puberty ${ }^{20}$. Similarly, the National Center for Health Statistics (NCHS) (2011) ${ }^{21}$, which says by sex $7,2 \%$ of men and $9,7 \%$ of women that the prevalence of women is higher than men. Respondents in this study were mostly in the final adolescent category with age 17-25 years.

Genetic Factors: There is a relationship between ALOX5's genetic polymorphism and the severity of asthma, whereas ALOX5 is the code of the enzyme that produces leukotriene, which plays the role of the severity of asthma. Genetic polymorphisms of ALOX5 as well as 5lipoxygenase-activating protein (FLAP) are associated with excessive production of leukotrienes. ALOX5 and FLAP are increased RNA messenger in peripheral blood leukocytes in asthmatics and leukotriene concentrations in 
sputum are greater in asthma patients compared with nonasthma $^{13}$.

Environmental factors (eg trigger exposure): To minimize the influence of environmental factors in this study respondents will always be required to report their activities during fish oil therapy, as factors such as contact with triggers, diet, excessive physical activity, etc. may affect the control of asthma symptoms.

Other therapies used. In the treatment history, most of the samples used inhaled beta-2 agonist drug inhalation group and all respondents were at step 1 treatment. Asthma treatment is divided into controller and reliever. Controller is a daily-used treatment in the long term to keep asthma under clinical control through its anti-inflammatory effects. While reliever is a treatment that is used when necessary and quickly to reduce bronchoconstriction and reduce the acute symptoms that accompany it. In this study, all respondents were at step 1, which means that none of the respondents used controller asthma medication to maintain their daily asthma control, and all respondents only used asthma medications when experiencing worsening symptoms (reliever). The main choice in this type of reliever is a short action beta-2 agonist which is generally salbutamol with inhalation route. Inhalation routes are preferred because they are topical, so side effects tend to be smaller and can work directly to the target site in the bronchioles. However, from the data of treatment used by respondents there are some respondents who use corticosteroids (oral or inhalation) and methylxanthine group which is actually an asthma therapy in the controller group $^{1}$.

Discussion of Lung Function Repair

From the research results can be seen that there is an increase in PEF value between the data before and after the patient get therapy. This indicates a potential effect after the respondents are given intervention in the form of fish oil. Improvement of asthma function may be influenced by other uncontrollable factors in research such as psychological (stress) ${ }^{22,23}$, unpredictable weather changes (such as cold or windy air) ${ }^{24,25}$ and daily activities ${ }^{26}$. During the measurement of PEF values, Which can be minimized the activity of respondents because it is done at the same time. The factors that affect the value of PEF but can be controlled in this study include food and drugs consumed. Foods such as fish that contain high protein can cause bias research results. And drugs like asthma medication can increase the value of PEF. However, it can be controlled from the presence of a log book given to the patient to be filled daily containing the activities carried out, drugs and food consumed, and adherence during the consumption of fish oil.

Limitations of Research

Criteria for inclusion of respondents such as heart and kidney history data were not accurately obtained. Because when respondents say that no history of heart and kidney is not supported by the results of checking the doctor first by using electrocardigram (ECG)

In this study using fish oil from a particular brand, which does not rule out the possibility that fish oil with other types can provide effects or not on research related asthma.
Researchers use this type of fish oil because the dose corresponds to the desired dose of fish oil is 1.0 grams. Therefore, respondents feel less comfortable to consume fish oil that is considered quite large because some respondents commented on soft capsule large enough. Increased prevalence of asthma occurs due to genetic and environmental factors. Asthma is a complex disease resulting from the interaction between genetic predisposition and environmental factors. Both of these factors not only affect the inflammatory process but also affect the complex and interactive phenotype.

The number of samples in this study were 26 people. Researchers have difficulty in finding a large number of samples to get valid results. Researchers should be able to work with health centers or other health agencies so that the number of samples can be reproduced.

Researchers cannot control racial factors that can affect genetic outcomes. Therefore it is necessary to do further research related to genetic influence (polymorphism of ALOX5) on therapeutic effect of fish oil containing omega-3.

\section{CONCLUSION}

Fish oil containing omega-3 for 4 weeks may decrease asthma symptoms in the asthma control level category and total ACT score. In addition, fish oil can also improve lung function significantly in every week.

\section{ACKNOWLEDGMENTS}

Acknowledgments to DIKTI 2017 and LPPM UBAYA for their support and support in conducting this research.

\section{REFERENCE}

1. The Global Initiative for Asthma (GINA). Update of the GINA Report. Global strategy for asthma management and prevention; 2016 [28 November 2016]. http://www.ginasthma.com/.

2. Direktorat Jenderal Pengendalian Penyakit dan Penyehatan Lingkungan. Pedoman Pengendalian Penyakit Asma. Depkes RI: Jakarta. 2009.

3. Direktorat Bina Farmasi Komunitas dan Klinik. Pharmaceutical Care Untuk Penyakit Asma. Depkes RI: Jakarta. 2007.

4. Oemiati R, Sihombing M, Qomariah. Faktor-Faktor yang Berhubungan dengan Penyakit Asma.di Indonesia. Media Litbang Kesehatan. 2010;20(1):41-9.

5. Badan Penelitian dan Pengembangan Kesehatan Departemen Kesehatan Republik Indonesia. 2008. Riset Kesehatan Dasar (RISKESDAS). 2007.

6. Rosenkranz RR. Rosenkranz SK. Neessen KJJ. Dietary factors associated with lifetime asthma or hayfever diagnosis in Australian middle-aged and older adults: a cross-sectional study. Nutrition Journal. 2012;11:84.

7. Aprizayanti. Hubungan Konsumsi Omega 3 Terhadap Tumbuh Kembang Anak Usia 2-3 Tahun di Wilayah Kerja Puskesmas Sebarang Padang Kota Padang Tahun 2011. Universitas Andalas: Padang. 2011.

8. Santoso A, Iriyanti N, S Tri Rahardjo. Penggunaan Pakan Fungsional Mengandung Omega 3, Probiotik dan Isolat Antihistamin $\mathrm{N}_{3}$ Terhadap Kadar Lemak dan 
Kolesterol Kuning Ayam Kampung. Jurnal Ilmiah Peternakan. 2013;1(3):848-855.

9. Thien FCK, S De Luca, RK Woods, MJ Abramson. Dietary marine fatty acids (fish oil) for asthma in adults and children (Review). Cochrane Database Syst Rev. 2010;2.

10. Miyata J, Arita M. Role of omega-3 fatty acids and their metabolites in asthma and allergic diseases. Allergol Int. 2015;64(1):27-34.

11. Arvaniti F, Priftis KN, Panagiotakos DB. Dietary habits and asthma: A review. Allergy Asthma Proc. 2010;31(2):e1-10.

12. McKeever TM, Britton J. Diet and Asthma. Am J Respir Crit Care Med. 2004;170:725-9.

13. Fotenko O, Zeki A, Schuster G, Davis C, Allayee H, Stephensen C, et al. Asthma patients with specific genotypes identified for fish oil treatment trial. California Agriculture. 2011;65(3):112-7.

14. Lorensia A, Wahjuningsih E, Supriadi. Keamanan Penggunaan Aminofilin pada Asma di Rumah Sakit Delta Surya Sidoarjo. Indonesia Journal of Clinical Pharmacy (IJCP). 2012;1(4):154-161.

15.Lorensia A, Ikawati Z, Andayani TM, Maranatha D, Wahjudi M. Analisis Kejadian Leukositosis Pasca Terapi Aminofilin Intravena Dibandingkan dengan Salbutamol Nebulasi pada Pasien Eksaserbasi Asma. Indonesia journal of Clinical Pharmacy (IJCP). 2016;5(3):149-159.

16. Lorensia A, Ikawati Z, Andayani TM, Maranatha D, Wahjudi M. Comparison of Electrolyte Disturbance of Using Intravenous Aminophylline versus Nebulization Salbutamol for Exacerbation Asthma in Surabaya, Indonesia. International Journal of Pharmaceutical and Clinical Research. 2016; 8(4): 221-228.

17. Nelson HS, Weiss ST, Bleecker ER, Yancey SW, Dorinsky PM. The Salmeterol Multicenter Asthma Research Trial: a comparison of usual pharmacotherapy for asthma or usual pharmacotherapy plus Salmeterol. Chest. 2006; 129(1):15-26.

18. Calder PC. Mechanisms of action of (n-3) fatty acids. J Nutr. 2012;142(3):592S-599S.

19. Moamary MSA, Al-Kordi AG, Ghobain MOA, Tamim HM. Utilization and responsiveness of the asthma control test (ACT) at the initiation of therapy for patients with asthma: a randomized controlled trial. BMC Pulmonary Medicine. 2012;12:14.

20. Waldron J. Asthma Care in the Community, John Wiley \& Sons, England. 2007.

21. National Center for Health Statistics (NCHS). Helath, United States, 2011: With Special Feature on Socioeconomic Status and Health. 2011 [28 November 2016]. https://www.cdc.gov/nchs/data/hus/hus11.pdf.

22. Lieshout RJV, MacQueen G. Psychological Factors in Asthma. Allergy Asthma Clin Immunol. 2008;4(1): 12-28.

23. Kullowatz A, Rosenfield D, Dahme B, Magnussen H, Kanniess F, Ritz T. Stress effects on lung function in asthma are mediated by changes in airway inflammation. Psychosom Med. 2008 May;70(4):46875.

24. Koskela H, Tukiainen H, Kononoff A, Pekkarinen H. Effect of whole-body exposure to cold and wind on lung function in asthmatic patients. Chest. 1994;105(6):1728-31.

25. Watanabe M, Noma H, Kurai J, Hantan D, Burioka N, Nakamoto S, Sano H, Taniguchi J, Shimizu E. Association between Outdoor Fungal Concentrations during Winter and Pulmonary Function in Children with and without Asthma. Int J Environ Res Public Health. 2016;13(5):452.

26. Ritz T, Rosenfield D, Steptoe A. Physical Activity, Lung Function, and Shortness of Breath in the Daily Life of Individuals with Asthma. CHEST 2010; 138(4):913-918. 


\section{International Journal of}

\section{Pharmaceutical Quality Assurance}

ISSN: 09759506

Peer Review Journal

doi prefix: $10.25258 /$ ijpqa

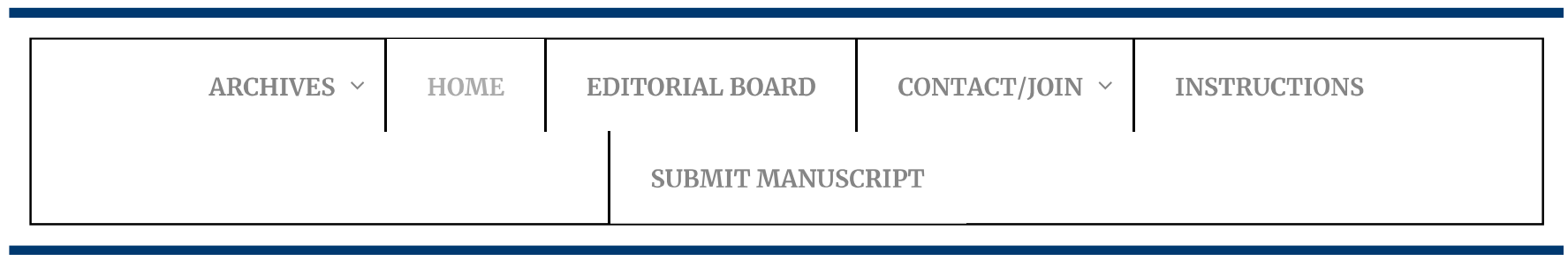

\section{Introduction}

INTERNATIONAL JOURNAL OF PHARMACEUTICAL QUALITY ASSURANCE is a quarterly international journal publishing the finest peer-reviewed research in the field of Pharamceutical Quality Assurance and Pharamceutical Analysis on the basis of its originality, importance, disciplinary interest, timeliness, accessibility, elegance and surprising conclusions. IJPQA also provides rapid, authoritative, insightful and arresting news and interpretation of topical and coming trends affecting science, scientists and the wider public

\section{Mission Statement}

First, to serve scientists through prompt publication of significant advances in the specified branch of Pharamceutical science, and to provide a forum for the reporting and discussion of news and issues concerning science. Second, to ensure that the results of Pharamceutical sciences are rapidly disseminated to the public throughout the world, in a fashion that conveys their significance for knowledge, culture and daily life.

\section{Editorial Policy}

The over-riding criteria for publication are originality, high scientific quality and interest to a multidisciplinary audience. Papers not sufficiently substantiated by experimental detail will not be published. Any technical queries will be referred back to the author, although the Editors reserve the right to make alterations in the text without altering the technical content. Manuscripts submitted under multiple authorship are reviewed on the assumption that all listed authors concur with the submission and that a copy of the final manuscript has been approved by all authors and tacitly or explicitly by the responsible authorities in the laboratories where the work was carried out. If accepted, the manuscript shall not be published elsewhere in the same form, in either the same or another 
language, without the consent of the Editors. Authors must state in a covering letter when submitting papers for publication the novelty embodied in their work or in the approach taken in their research.

\section{Ethical Statement}

IJPQA insists on ethical practices in both human and animal experimentation. Evidence for approval by a local Ethics Committee (for both human as well as animal studies) must be supplied by the authors on demand. Animal experimental procedures should be as humane as possible and the details of anaesthetics and analgesics used should be clearly stated. The ethical standards of experiments must be in accordance with the guidelines provided by the CPCSEA (animal) and ICMR (human). The journal will not consider any paper which is ethically unacceptable. A statement on ethics committee permission and ethical practices must be included in all research articles under the 'Materials and Methods' section.

Authors must be careful when they reproduce text, tables or illustrations from other sources. Plagiarism will be viewed seriously. All accepted papers are subject to editorial changes.

\section{Publication Frequency}

IJPQA will be published quarterly in the month of March, June, September, December of every year.

Impact Factor: 1.041
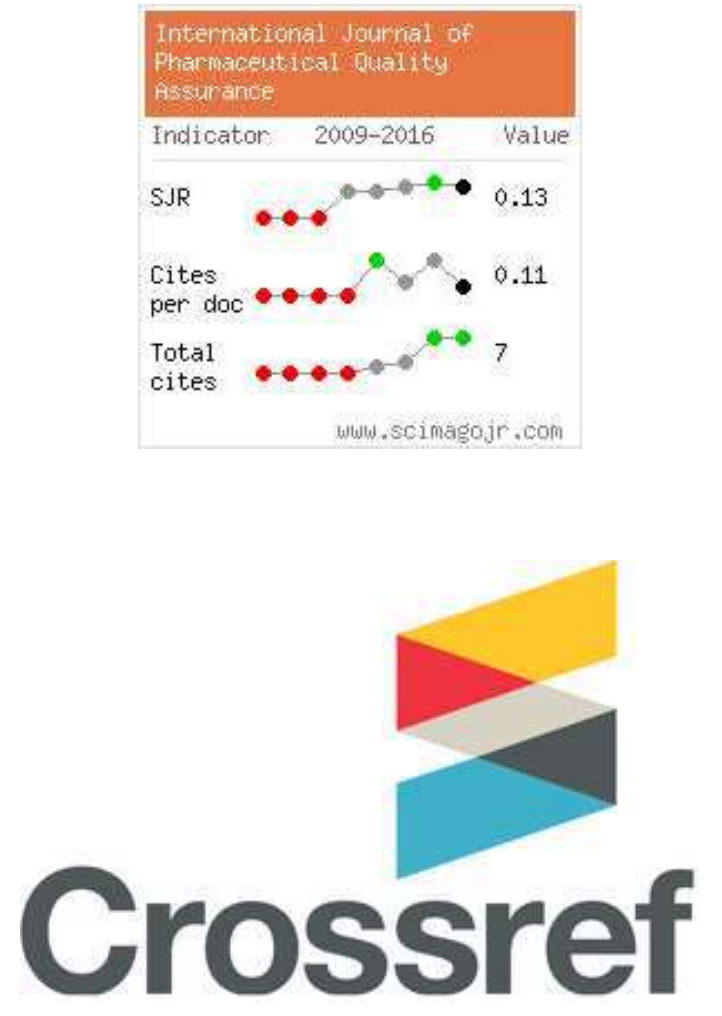

UGC approved Journal 


\section{International Journal of}

\section{Pharmaceutical Quality Assurance}

ISSN: 09759506

Peer Review Journal

doi prefix: $10.25258 /$ ijpqa

\begin{tabular}{|l|l|l|l|l|}
\hline ARCHIVES $\vee$ & HOME & EDITORIAL BOARD & CONTACT/JOIN $\vee$ & INSTRUCTIONS \\
\hline
\end{tabular}

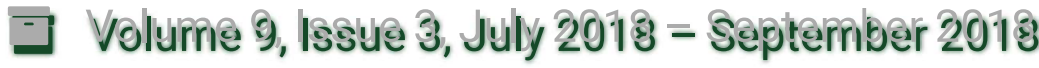

1. Antibacterial Effectiveness of Chloramphenicol Ophthalmic Hydrogel Against Staphylococcus aureus ATCC 25923 and Bacillus subtilis ATCC 6633

Kurniawansyah I S, Sulistiyaningsih, Maulia M G, Budiman A

Abstract

ent

2. Linagliptin: A Review on Bio-analytical and Analytical Methods

Kirtimaya Mishra, Balamurugan K, Suresh R

Abstract

3. Development and Validation of UV-spectrophotometric Procedures for Efavirenz Quantitative Determination Slabiak Oksana I, Ivanchuk Iryna M, Klimenko Lina Yu, Tokaryk Galyna V, Kolisnyk Iuliia S

Abstract

4. Present Status of Supplemental Application Submission in USFDA

Misri P, Verma S, Yashwant, Haque A

Abstract 
5. Pharmacognostic and Pharmacological Studies on Flower Buds of Capparis spinosa L.

Sambasivam Manikandaselvi, Pemaiah Brindha, Vellingiri Vadivel

Abstract

6. Novel Electro Polymerization Method to Synthesized Anti-corrosion Coated Layer on Stainless Steel Surface from (N-Benzothiazolyl Maleamic Acid) and Study its Biological Activity

Khalil S Khalil, Khulood A Saleh, Muna I Khalaf

Abstract

7. Effectiveness of Fish Oil Containing Omega-3 in Improving Symptoms and Lung Function in Asthma Outpatient in Surabaya, Indonesia

Amelia Lorensia, Mariana Wahyudi, Nadia Aisah Mayzika

Abstract

8. 3D Printing: An Emerging Technology in Pharmaceuticals

Sharma S, Saxena V

Abstract

9. Study of Diabetic Mellitus and Knowledge of Lotion Foot Care on the Community

Athiyah U, Hendradi E, Rosita N, Erawati T, Purwanti T, Hariyadi DM

Abstract

10. Comparative Study of the Biologically Active Substances Composition and Content in Meadowsweet (Filipendula ulmaria (L.) Maxim) Crude Herbal Drugs (Herb, Leafs, Flowers) of Russian Origin

Tatyana Yuryevna Kovaleva, Valentina Alekseevna Ermakova, Daria Aleksandrovna Trashchenkova, Ekaterina Anatolievna Dorovskih, Dmitry Olegovich Bokov, Inessa Vladimirovna Shilova, Irina Aleksandrovna Samylina

Abstract

11. Validation and Various Qualifications in HVAC System - A Review from Pharmaceutical Quality Assurance Prospect

Varun kumar K R, Amit B Patil, Ajay P Karnalli

Abstract

-

12. Technology Transfer in Pharmaceutical Manufacturing - A Review

Bharath Kumar B, Amit B Patil, Ajay P Karnalli

Abstract 
13. Development and Validation of HPLC/UV-Spectrophotometric Procedures for Metronidazole Quantitative Determination

Klimenko Lina Yu, Shkarlat Galyna L, Shovkova Zoia V, Yaremenko Vitaliy D, Shpychak Oleg S

Abstract

14. In vitro Anti-Helminthic Study of Ficus Dalhousiae Leaf Extracts in Pheretima posthuma Mohammed Idrees Hussain, Syed Safiullah Ghori

Abstract

15. Molecular Detection of wzx 1 and wzy Genes in Multi Drugs Resistance E. coli Isolates Mona Al-Terehi, Saba Saadoon Khazaal, Haidar J Muhammed, Russul Hikmat Behjet

Abstract

16. Relationship Between Chordin Like-1 Protein Level and Patients with Pulmonary Arterial Hypertension Disease

Mohammed Noori Al-Dujaili, Khamaal Hussein Abod Al-Khafaji, Arshad Noori Ghani Al-Dujail

Abstract

17. Molecular Detection of Human Papilloma Virus $31 \& 33$ in Prostate Carcinoma and Prostate Benign Tissues from a Group of Iraqi Patients

Noor Sami Al- Lebawy

Abstract

ne

18. Analysis of the Glycine max role of Syntaxin (SYP22) in resistance to Rotylenchulus reniformis Weasam A R Aljaafri, Fadhal A Al-fadhal, Ameera Naji Hussein Al-jouburi

Abstract

19. Detection of Aspergillus fumigatus by Polymerase Chain Reaction (PCR)

Zainab H Abood AL-Asadi

Abstract

20. Effect of Allicin in Reducing the Cytotoxicity of Cyclophosphamide on Reproductive System of Wister Male Rats

Saadeya Ali Lefelef Al-Gnami, Hussein Khudair Aubaies Al-Mayali

Abstract 
21. Electroencephalogram and Visual Evoked Potential Studies in Patients with Stroke Sura ZaKi Gaffat AL-Nasriwy, Farah Nabil Abbas, Abdul-Kareem Al bermany, Fizel Abbas Al-Himyari

Abstract

22. Histological and Physiological Study of the Effect of Silver Nanoparticles and Omega-3 on Asthma of Male Mice Induced by Ovalbumin

Leena Adeeb Mehdi AL-waealy, Arsha D Noori Ghani Al-Dujaili

Abstract
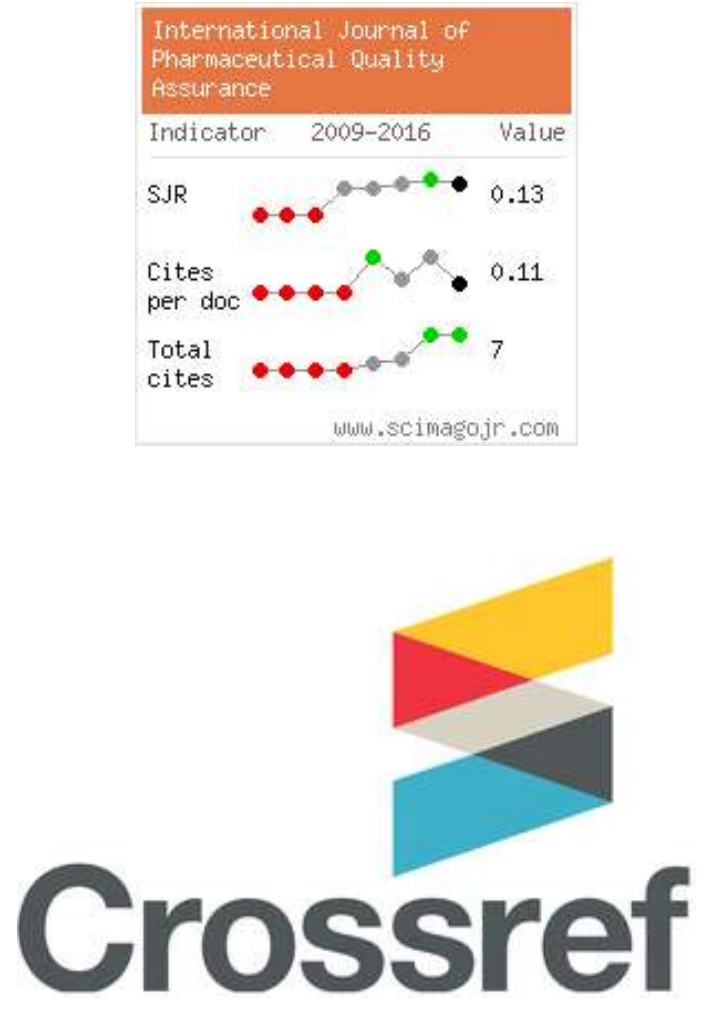

UGC approved Journal

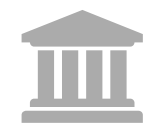

This journal is present in UGC approved List of Journals for the purpose of Career Advancement Scheme (CAS) and

Direct Recruitment of Teachers and other academic staff as required under the UGC (Minimum Qualifications for Appointment of Teachers and other Academic Staff in Universities and Colleges) 


\section{International Journal of}

\section{Pharmaceutical Quality Assurance}

ISSN: 09759506

Peer Review Journal

\section{doi prefix: $10.25258 / \mathrm{ijpqa}$}

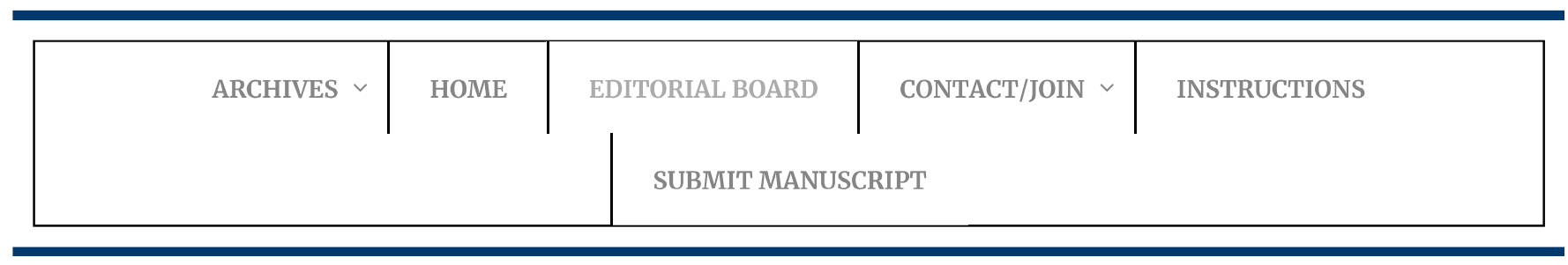

Editor in Chief

\section{Dr. Jitender Bariwal}

Department of Pharmaceutical Sciences

College of Pharmacy

University of Nebraska Medical Center

985965 Nebraska Medical Center

Omaha, NE

Past: Principal \& Professor, Shiva Institute of B. Pharmacy,

Chandpur, Bilaspur, Himachal Pradesh-174004, India

Past: Department of Chemistry, Katholieke Universitiet,

Celestijaanlaan, Leuven, BELGIUM

Scopus ID: Visit scopus ID link

Google Scholar Profile: Visit google scholar ID

\section{Board Members}

Dr. Jawed Akhtar

School of Pharmaceutical Sciences,

Jaipur National University, Jaipur, Rajasthan, India

Dr. Ajay K. Gaur

Lachoo Memorial College of Pharamcy,

Jodhpur, Rajasthan, INDIA 
Dr. Vijay K Sharma

Team Member, Cipla Pharmaceuticals,

Mumbai, INDIA

Dr Rakesh Yadav

Department of Pharmacy, Banasthali University

Banasthali, Rajasthan 304022, India

Dr. Lakshmi T

No.162 Saveetha Dental College \& Hospitals ,Chennai

P.H Road, Velappanchavady Chennai, India

Dr.Malladi Srinivasreddy

Vaageswari College of Pharmacy, Karimnagar,

TS (505481)-India.

Dr. Jineet kumar Gawad

St. John Institute of Pharmacy \& Research, Manor Road

Palghar (East), Maharashtra Palghar, India

Dr. Yasir Mehmood

University of Central Punjab

lahore, punjab 54000, Pakistan

Dr. Vaseeha Banu T.S

M.M.U.College of Pharmacy, Ramadevara Betta Road

K.K.Doddi Ramnagara-562159, India

Dr.Shanmugam Ramaswamy

Department Of Pharmaceutical Analysis, Sree Vidyanikethan College of Pharmacy

Sai nagar, Rangapet Tirupati, India

Dr. Kalpana Nagpal

Assistant Professor

Amity University, Noida, India

Dr. Ashish Suttee

Assistant Professor

Lovely Professional University, Phagwara, India

Impact Factor: 1.041 


\title{
SJR
}

\section{International Journal of Pharmaceutical Quality Assurance}

\author{
Country India - III SIR Ranking of India \\ Subject Area and Category Pharmacology, Toxicology and Pharmaceutics \\ Pharmacology, Toxicology and Pharmaceutics (miscellaneous) \\ Publisher In-IJPQA \\ $\mathrm{H}$ Index \\ Publication type Journals \\ ISSN 09759506 \\ Coverage 2011, 2013-ongoing \\ ? How to publish in this journal \\ Join the conversation about this journal
}

Quartiles

Pharmacology, Toxicology and Pharmaceutics (miscellaneous)

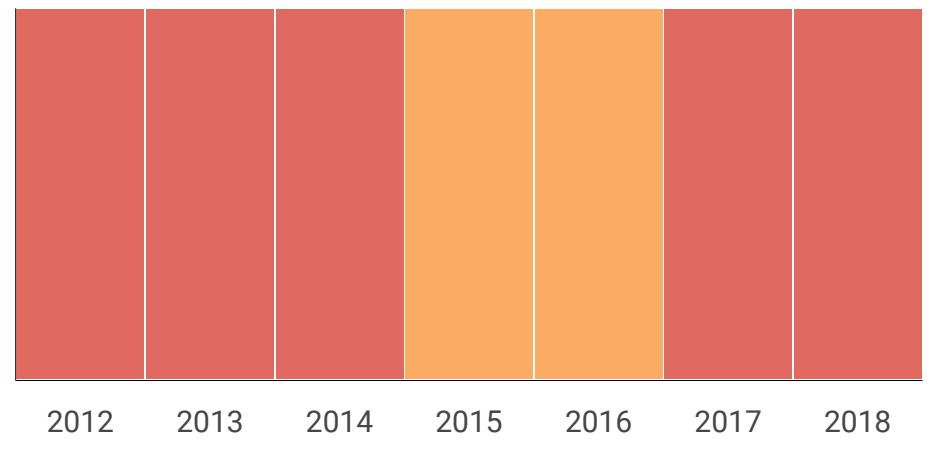

SJR 


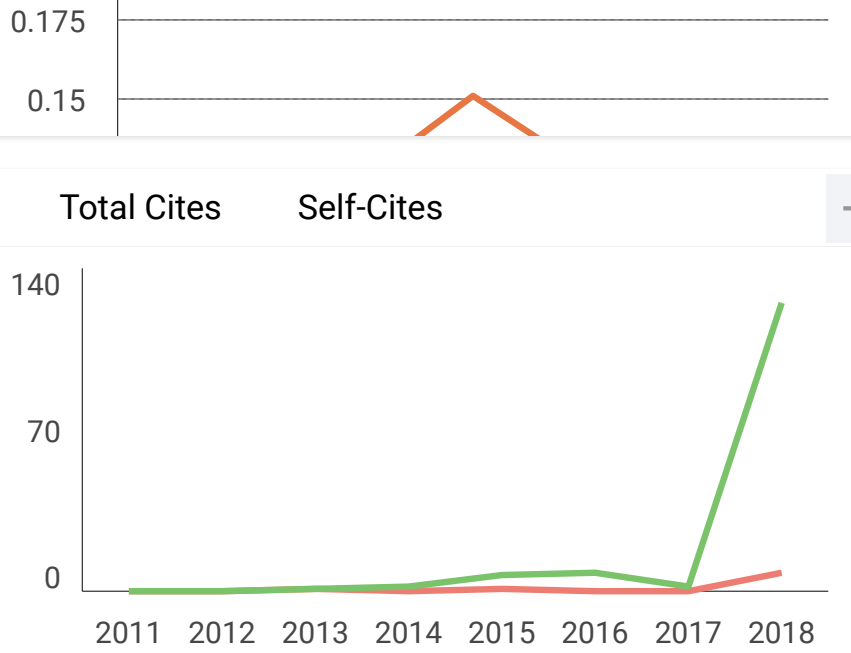

External Cites per Doc

Cites per Doc

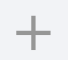

2

2

1

0

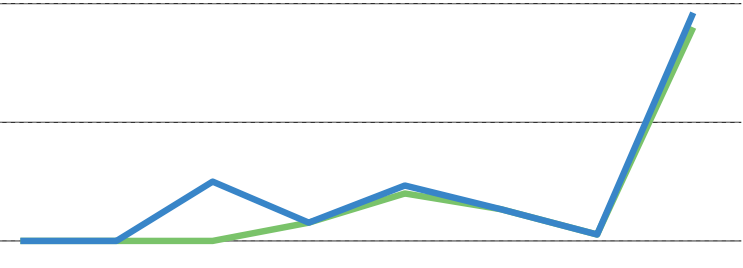

$\begin{array}{llllllll}2011 & 2012 & 2013 & 2014 & 2015 & 2016 & 2017 & 2018\end{array}$

Citable documents Non-citable documents † 80

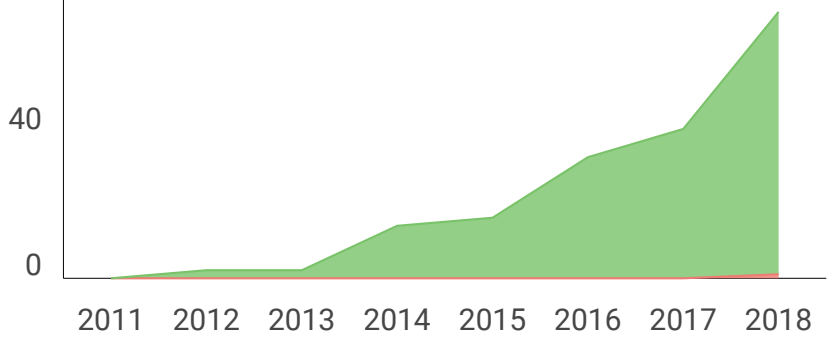

International Journal of Pharmaceutical Quality...

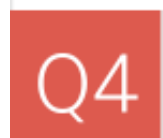

Pharmacology,

Toxicology and

Pharmaceutics... best quartile

SJR 2018

0.12

powered by scimagoir com
2.8

1.4

0.7

0

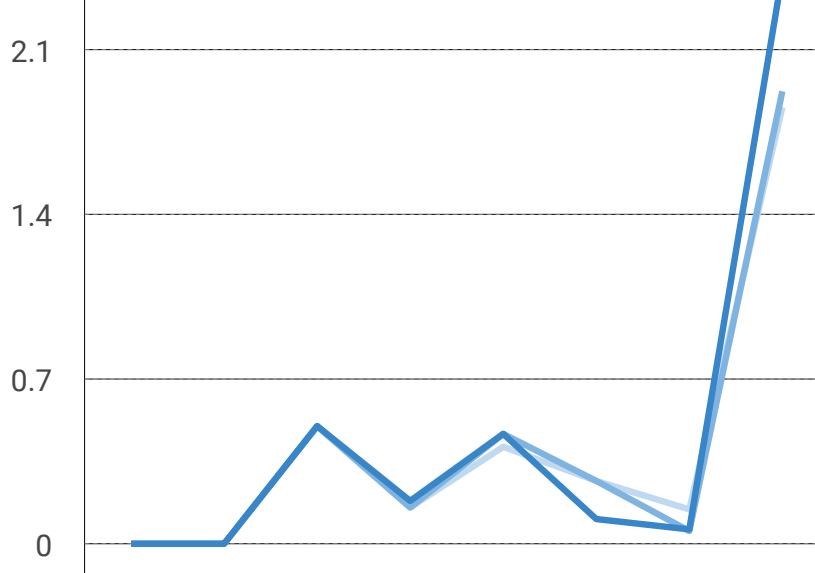

\% International Collaboration

40

20

0

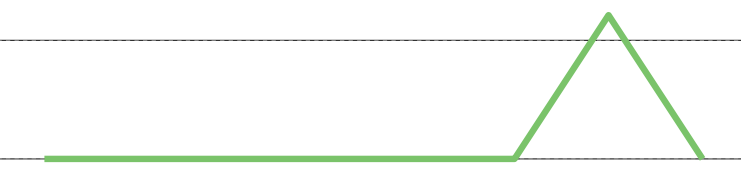

$201120122013201420152016 \quad 2017 \quad 2018$
80

40

0 $\begin{array}{llllllll}2011 & 2012 & 2013 & 2014 & 2015 & 2016 & 2017 & 2018\end{array}$ 


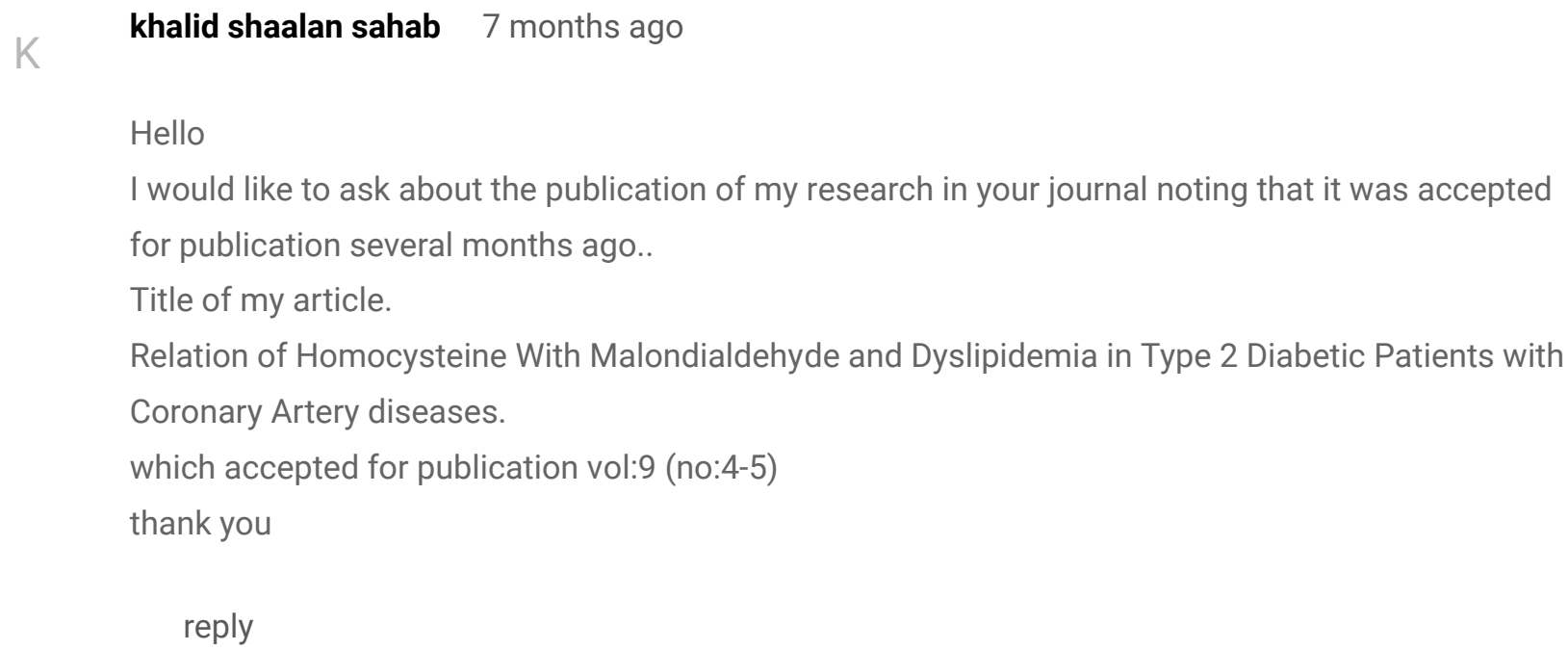

\section{S Suhad mohammed 9 months ago}

Hello

I would like to ask about the publication date of my research in your journal noting that it was accepted for publication several months ago..

Title of my article..

Anticancer activity assay of some purification compounds extracted from pleurotus ostreatus. Thank you

reply

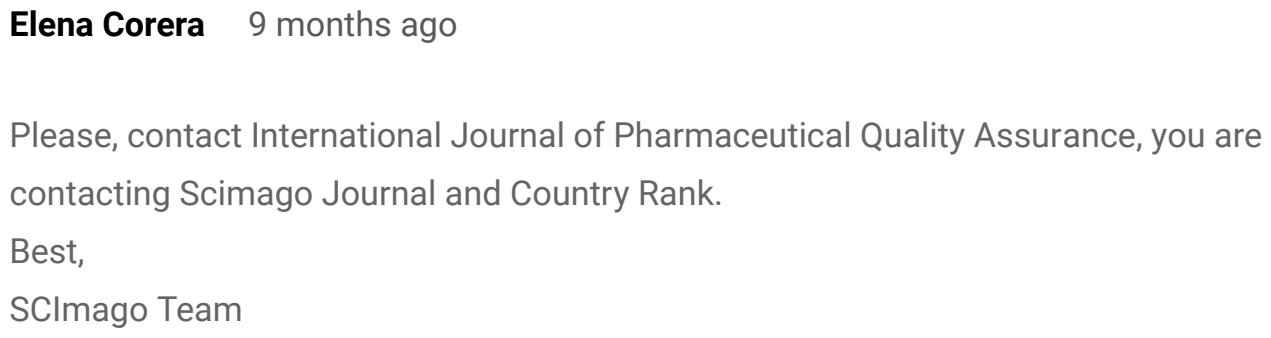

Mohammed Kadhim 11 months ago

good greeting

When to publish my research

Preparation and Characterization Teeth Filling of PMMA / n-TiO2 
To Wear Resistance and Netscape

Vol: 9 (No.:5-6)

reply

\section{Elena Corera 11 months ago}

Dear Mohammed,

thank you very much for your comment. Unfortunately, we cannot help you with your request, we suggest you contact journal's editorial staff so they could inform you more deeply. You can find contact information in SJR website https://www.scimagojr.com

Anyway, if there is any user who has already published in the journal, maybe could help us with your request.

Best Regards,

SCImago Team

M

Mohammed Kadhim 11 months ago

Preparation and Characterization Teeth Filling of PMMA/ n-TiO2

To Wear Resistance and antibacterial

We wish to bring to your kind notice the following

$\checkmark$ We acknowledge the receipt of the above mentioned article.

$\checkmark$ The above mentioned article(s) has been sent to the reviewer of expert comments

$\sqrt{ }$ The above mentioned article(s) (IJPQA A210) have been accepted for publication in the Vol:9 (No.:5-6) to get release in October 2018):(International Journal of Pharmaceutical Quality Assurance ISSN: 0975-9506).

reply

Elena Corera 11 months ago

Thank you for your participation! 


\section{F $\quad$ Furqan 1 year ago}

What is the instructions?

reply

\section{Elena Corera 1 year ago}

Dear Furqan, in the link below you will find the information corresponding to the author's instructions of this journal. Best regards, SCImago Team

https://www.elsevier.com/journals/international-journal-of-pharmaceutics/0378-5173/guidefor-authors

\section{Leave a comment}

\section{Name}

\section{Email}

(will not be published)

I'm not a robot

reCAPTCHA Privacy-Terms

\section{Submit}

The users of Scimago Journal \& Country Rank have the possibility to dialogue through comments linked to a specific journal. The purpose is to have a forum in which general doubts about the processes of publication in the journal, experiences and other issues derived from the publication of papers are resolved. For topics on particular articles, maintain the dialogue through the usual channels with your editor. 


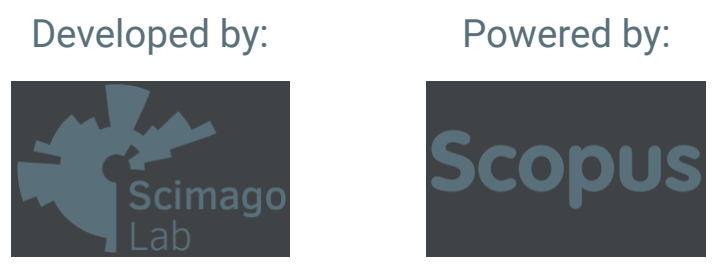

Follow us on @ScimagoJR

Scimago Lab, Copyright 2007-2019. Data Source: Scopus ${ }^{\circledR}$

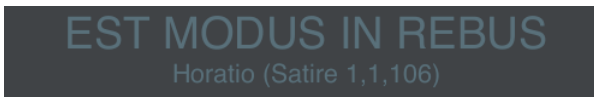




\section{Effectiveness_of_Fish_Oil_Conta ining_Omega.pdf \\ by Mariana Lorensia}

Submission date: 16-Jan-2020 12:03PM (UTC+0700)

Submission ID: 1242518837

File name: Effectiveness_of_Fish_Oil_Containing_Omega.pdf (259.84K)

Word count: 5196

Character count: 26677 
Available online on www.ijpqa.com

International Journal of Pharmaceutical Quality Assurance 2018; 9(3); 260-266

doi:

Research Article

ISSN 09759506

\title{
Effectiveness of Fish Oil Containing Omega-3 in Improving Symptoms and Lung Function in Asthma Outpatient in Surabaya, Indonesia
}

\author{
Amelia Lorensia $^{1 *}$, Mariana Wahyudi ${ }^{2}$, Nadia Aisah Mayzika $^{3}$ \\ 31 \\ ${ }^{I}$ Departement of Clinical-Community Pharmacy, Faculty of Pharmacy, University of Surabaya (Universitas Surabaya \\ $7 \quad(U B A Y A))$, Surabaya \\ ${ }^{2}$ Departement of Purification and Molecular Biology, Faculty of Biotechnology, University of Surabaya (Universitas \\ 30 Surabaya (UBAYA)), Surabaya \\ ${ }^{3}$ Postgraduate Student of Master of Pharmacy Science, Faculty of Pharmacy, University of Surabaya (Universitas \\ Surabaya (UBAYA)), Surabaya
}

Received: $25^{\text {th }}$ Apr, 18; Revised: $2^{\text {nd }}$ Aug, 18, Accepted: $25^{\text {th }}$ Aug, 18; Available Online: $25^{\text {th }}$ Sep, 2018

\begin{abstract}
Indonesia as a potential maritime country 37 fish production, can be processed into fish oil containing omega-3. Based on previous libraries, omega- 3 fish oils can be used to improve asthma cor 27 and improve lung function. The effects of a 2 ug are individualized depending on genetic and environmental factors. The aim of the study was to investigate the effect of fish oil containing omega- 3 on improving asthma symptoms and improving lung function. The research n 42 od used is pre-post test design, using data collection technique with asthma control test questionnaire to see clinical symptoms of asthma and measure lung function with peak flow meter. Intervention given is a fish oil product with once daily doses, then follow up every week for 4 weeks. The subject of research is adult age. Pulmonary function data and asthma symptoms will be tested for normality with shapiro-wilk test and followed by anova one way. The research was conducted in $516-$ 2017 in Surabaya and the data obtained 28 respondents. At the control level of asthma and total ACT score $(\mathrm{P}<0.05)$ it can be concluded that there was significant difference between before and after omega- 3 fish oil therapy for 4 weeks. In the improvement of lung function there is a significant improvement of lung function starting from before therapy until the increase every week until the 4th week. Fish oil containing omega 3 for 4 weeks may decrease asthma symptoms in the asthma control level category and total ACT score. In addition, fish oil can also improve lung function significantly in every week.
\end{abstract}

Keywords: asthma, fish oil contains omega-3, asthma symptoms, lung function.

\section{INTRODUCTION}

Asthma is a heterogeneous dis 29 e in the form of chronic respiratory tract inflammation characterized by respiratory symptoms such as wheezing, shortness of breath, feeling depressed in the chest and cough. Despite the low level of fatality but then 23 umber of cases is quite common in the community. The World Health Organization (WHO) estimates that 100-150 million people worldwide suffer from asthma. Even this number is expected to con 15 ue to grow to reach 180,000 people every year $^{1-2}$. Adverse effects of asthma include decreased quality of life, decreased productivity, school absenteeism, increased healthcare costs, hospital care risks and even death ${ }^{3}$. Increases in the prevalence of asthma in Asia such as Singapore, Taiwan, Japan or South Korea are 15 o striking. The incidence of asthma has increased over 4 teen years, both in developing and developed countries. In Indonesia, the prevalence $4 \mathrm{f}$ asthma is not known for certain, but it is estimated that 2-5\% of Indonesia's population suffers from asthma. The Department of Health estimates that asthma is among the top 10 causes of illness and mortality in hospitals and an estimated 10\% of Indonesia's 25 million people suffer from asthma. The prevalence of asthma in urban areas is generally higher than in rural areas, as urban lifestyle increases the risk of asthma. According to RISKESDAS (2013) asthma prevalence in Indonesia reached $4.5 \%$ with asthma prevalence in East Java $5.1 \%{ }^{4-}$ 5.

In Indonesia, which is a maritime country, has great potential in fish production and even the government also launched GEMARIKAN in 2014, to popularize fish consumption. Fish has been known to be processed into fish oil containing high omega-3. Fish consumption can 35 vent asthma in adult patients. Research has shown that fish consumption at least once a month can reduce the risk of asthma ${ }^{6}$. In the meantime, several fish oilrelated studies, including omega- $3 \mathrm{~s}$ as Aprizayanti $(2011)^{7}$ and Santoso et al. $(2013)^{8}$. Omega-3 has been used only as a supplement in helping the child's growth process, help lower cholesterol, heart disease. High intake of fish oil 1 as protective effect against asthma and or allergies ${ }^{9}$. Omega-3 polyunsaturated fatty acids (n-3 PUFAs) consisting of eicosapentaenoic acid (EPA) and docosahexaenoic acid (DHA) are found primarily in

*Author for Correspondence: amelia.lorensia@gmail.com 
Table 1: Frequency Distribution of Respondent Characteristics.

\begin{tabular}{llll}
\hline Characteristics & & Number (n: 26) & Percentage (\%) \\
\hline Gender & Male & 7 & 27,00 \\
& Female & 19 & 73,00 \\
Age (years) & 34 uth end (17-25) & 25 & 96,15 \\
& Early adult (26-35) & 1 & 3,85 \\
History of Asthma & Oate adult (36-45) & 0 & 0,00 \\
Treatment based on agonist beta-2 short acting & Inhaled agonist beta-2 short acting & 8 & 21,05 \\
Global Initiative for & Oxygen \\
Asthma (2016) & Not taking any medication & 10 & 26,31 \\
& Oral corticosteroids (used only when symptoms & 1 & 2,63 \\
& worsen) & 3 & 7,89 \\
& Oral methylxanthine (used only when symptoms & 3 & 2,63 \\
& worsen) & & 11,53 \\
\hline
\end{tabular}

Table 2: Frequency Distribution Assessment of Asthma Symptoms Based on ACT.

\begin{tabular}{|c|c|c|c|}
\hline \multirow[t]{2}{*}{ Asthma Assessment Category } & & \multicolumn{2}{|c|}{ Number of Respondents } \\
\hline & & $\mathrm{ACT}_{0}$ & $\mathrm{ACT}_{4}$ \\
\hline Asthma Control Based on & Every now and then & 1 & 0 \\
\hline \multirow[t]{3}{*}{ Activity Limitations } & Too often & 0 & 0 \\
\hline & Often & 2 & 4 \\
\hline & Not too often & 14 & 16 \\
\hline 20 & Never & 9 & 6 \\
\hline Asthma Control Based on & More than once a day & 0 & 0 \\
\hline Frequency of Shortness of & 22 ce a day & 0 & 0 \\
\hline \multirow[t]{3}{*}{ Breath } & 3-6 times a week & 5 & 3 \\
\hline & Once or twice a week & 14 & 14 \\
\hline & 111. a week at all & 7 & 9 \\
\hline Asthma Control Based on & 4 or more nights per week & 2 & 2 \\
\hline Symptoms Symptom Asthma & 2-3 nights per week & 3 & 1 \\
\hline \multirow[t]{2}{*}{ At Night or Morning } & once a week & 4 & 0 \\
\hline & Once or twice & 6 & 14 \\
\hline 20 & $8 \mathrm{t}$ at all & 11 & 9 \\
\hline Asthma Control Based on & 3 or more per day & 1 & 0 \\
\hline Frequency of Asthma Drug & 1 or 2 times per day & 2 & 3 \\
\hline \multirow[t]{3}{*}{ Use } & 2 or 3 times per week & 4 & 5 \\
\hline & Once a week or less & 5 & 4 \\
\hline & not at all & 14 & 14 \\
\hline Asthma Control Based on & Not controlled at all & 8 & 3 \\
\hline \multirow[t]{4}{*}{ Asthma Control Level } & Less controlled & 6 & 5 \\
\hline & Simply controlled & 6 & 8 \\
\hline & Well controlled & 4 & 6 \\
\hline & Full controlled & 0 & 4 \\
\hline \multirow[t]{3}{*}{ ACT Total } & Uncontrolled (total value of ACT: <19) & 17 & 11 \\
\hline & Partially controlled (total value ACT: $20-24$ ) & 5 & 13 \\
\hline & Full controlled (total value ACT: 25 ) & 4 & 2 \\
\hline
\end{tabular}

fish oil. Epidemiologic 26 tudies show that omega-3 has a protective effect against cardiovascular disease myocardial infarction or cerebral infarction, hyp 3 ension, and hyperlipidemia. In addition, omega-3 has beneficial effects on chronic inflammatory diseases including chronic obstructive pulmonary disease (COPD), asthma, rheum 3 pid arthritis, and inflammation of the intestine. Atopic sensitization and allergies can also be prevented with fish intake during pregnancy ${ }^{10}$.

In Indonesia has conducted several studies related to fish oil, which among others contain omega-3. Omega- 3 is used as a supplement in helping the child's growth process, help lower cholesterol, heart dise $10^{7,8,10,11,12}$. But there has been no research related to the effect of omega-3 on the improvement of asthma in Indonesia. The antiinflammatory effect on omega-3 is due to the content of EPA which is a competitive substrate with arachidonate so it has the potential to reduce inflammation of the respiratory tract and bronchoconstriction. This has led to a new understanding over the last 30 years that fish oil deficiency can a 10 avate asthma ${ }^{13}$.

This study aims to determine the effect of omega- 3 on the control of asthma in patients with asthma in Surabaya who 
Table 3: ACT Normality Assessment Test Group Intervention

\begin{tabular}{llll}
\hline Asthma Assessment Category & \multicolumn{3}{c}{ P value } \\
\cline { 2 - 4 } & $\mathrm{ACT}_{0}$ & $\mathrm{ACT}_{4}$ & Conclusion 9 \\
\hline Activity Limitations & 0,00 & 0,00 & Distribution of data is not normal \\
Frequency of Shortness of Breath & 0,00 & 0,00 & Distribution of 9 ta is not normal \\
Asthma Symptoms At Night or Morning & 0,00 & 0,00 & Distribution of data is not normal \\
Frequency of Asthma Drug Use & 0,00 & 0,00 & Distribution of 9 ta is not normal \\
Level of asthma control & 0,001 & 0,044 & Distribution of data is not normal \\
ACT Total & 0,558 & 0,460 & Distribution of data is normal \\
\hline
\end{tabular}

$\mathrm{P}>0.05$ means normal distribution; $\mathrm{P}<0.05$ means the distribution is not normal

Table 4: Changes in ACT Value as Asthma Symptoms

\begin{tabular}{|c|c|c|c|}
\hline \multirow[t]{3}{*}{ Asthma Assessment Category } & \multicolumn{3}{|c|}{ Number of Respondents } \\
\hline & \multicolumn{3}{|c|}{ Change the value of $\mathrm{ACT}_{0}$ to $\mathrm{ACT}_{4}$} \\
\hline & Up & Constant & Down \\
\hline Activity Limitations & 5 & 15 & 6 \\
\hline Frequency of Shortness of Breath & 6 & 18 & 2 \\
\hline Asthma Symptoms At Night or Morning & 6 & 17 & 3 \\
\hline Frequency of Asthma Drug Use & 4 & 17 & 5 \\
\hline Level of asthma control & 16 & 9 & 1 \\
\hline ACT Total & 15 & 6 & 5 \\
\hline
\end{tabular}

Table 5: ACT Differences Test Before and After Omega-3 Fish Oil Therapy.

\begin{tabular}{|c|c|c|c|c|c|}
\hline \multirow[t]{2}{*}{ Asthma Assessment Category } & \multicolumn{2}{|c|}{ Average } & \multicolumn{3}{|c|}{ Test the Difference } \\
\hline & $\mathrm{ACT}_{0}$ & $\mathrm{ACT}_{4}$ & P value & Type of Test Used & Conclusion 18 \\
\hline Activity Limitations & 3,81 & 4,08 & 0,763 & Friedman Test & $\begin{array}{l}\text { There is no significant } \\
\text { difference }\end{array}$ \\
\hline $\begin{array}{l}\text { Frequency of Shortness of } \\
\text { Breath }\end{array}$ & 4,08 & 4,23 & 0,157 & Friedman Test & $\begin{array}{l}\text { There is no significant } \\
\text { difference }\end{array}$ \\
\hline $\begin{array}{l}\text { Asthma Symptoms At Night or } \\
\text { Morning }\end{array}$ & 3,81 & 4,04 & 0,317 & Friedman Test & $\begin{array}{l}\text { There is no significant } \\
\text { difference }\end{array}$ \\
\hline Frequency of Asthma Drug Use & 4,12 & 4,12 & 0,739 & Friedman Test & $\begin{array}{l}\text { There is no significant } \\
\text { difference }\end{array}$ \\
\hline Level of asthma control & 2,08 & 3,12 & 0,00 & Friedman Test & $\begin{array}{l}\text { There is a significant } \\
\text { difference }\end{array}$ \\
\hline $\begin{array}{l}\text { ACT Total } \\
17\end{array}$ & 17,89 & 19,58 & 0,041 & Anova One Way & $\begin{array}{l}\text { There is a significant } \\
\text { difference }\end{array}$ \\
\hline
\end{tabular}

0.05 , Ho accepted means there is no significant difference

$\mathrm{P}<0.05$, Ho rejected means there is a significant difference

will be given fish oil. During this treatment asthma focuses on therapy with long-term synthetic drugs, which can cause problems such as: the use of aminophylline which is a drug with a narrow range of therapy so that the risk of causing side effects ${ }^{14,15,16}$, single use of long-acting beta- 2 agonist that can aggravate Exacerbation of asthma ${ }^{17}$, or the use of inhaled corticosteroids that may cause oropharyngeal candidiasis and even lung infec $2 \mathrm{~ns}^{1}$.

This study aims to determine the effect of fish oil containing omega-3 to improve asthma symptoms and improve lung function. Patients with a high level of education influence self evaluation so that it can affect the patient's asthma control level. This study uses research subjects with a minimum education level of high school with the hope that the level of asthma control is good, and is expected this study can also increase knowledge related to the influence of nutrition on asthma, in the role of pharmacist to support the handling of asthma by motivating patients to be obedient in treatment, Provide information, counseling, and education so that they better understand the treatment regimen provided so that patients can be more actively involved in their treatment which can improve their 5 herence to drug use. Treatment of asthma is a long-term treatment and adherence to medication and treatment is desirable. It is expected that good patient compliance will affect the number of drugs used less, fewer doses per day, the incidence of drug side effects is less common ${ }^{3}$.

\section{METHOD}

This research uses pre-post test design method. This study used data collection techniques with Asthma Control Test questionnaire to see clinical symptoms of asthma and measure lung function with peak flow meter tool. Each sample of the study was given fish oil. Intervention given is a fish oil products circulating in Indonesia. Fish oil is given to patients with once daily doses, then follow up every week for 4 weeks. Dosage of fish oil containing 
Amelia et al. / Effectiveness of Fish...

Tabel 6: Rata-rata Nilai PEF dan Uji Normalitas Persebaran Data Fungsi Paru.

\begin{tabular}{llllll}
\hline Group & $\begin{array}{l}\text { Average } \\
\text { (L/sec) }\end{array}$ & PEF & Value & \multicolumn{3}{c}{ Test Data Normality } \\
\cline { 4 - 5 } & 217,96 & & Type of Test Used & P value & Conclusion \\
\hline $\mathrm{PEF}_{0}$ & 273,15 & & Shapiro wilk & 0,002 & No normal \\
$\mathrm{PEF}_{1}$ & 295,56 & & Shapiro wilk & 0,131 & Normal \\
$\mathrm{PEF}_{2}$ & 298,89 & & Shapiro wilk & 0,109 & Normal \\
$\mathrm{PEF}_{3}$ & & Shapiro wilk & 0,209 & Normal \\
$\mathrm{PEF}_{4}$ & 325,00 & 19 & Shapiro wilk & 0,089 & Normal \\
\hline $\mathrm{P}$ & &
\end{tabular}

$\mathrm{P}>0.05$ means normal distribution; $\mathrm{P}<0.05$ means the distribution is not normal

omega-3 recommended by 1 gram to 5.4 gram per day ${ }^{18}$, then 4 this study selected fish oil with dose of 1.0 gram.

The independent variable of this research is fish oil. While the dependent variables of this study are symptoms of asthma and lung function, with controlled variables according to inclusion and exclusion criteria.

Symtoms of asthma: Symptoms of asthma were measured by using the Asthma Control Test (ACT) questionnaire. ACT is 41 of the specific instruments in assessing asthma control in patients with chronic asthma. Co 32 ting of 5 questions that include activity limitation, shortness of breath, asthma symptoms at night, frequency of reliever drug use, and asthma control rate counted for 4 weeks. Each question is given a choice of 5 - Likert ${ }^{1,19}$. Symptoms of asthma were measured 2 times, ie, at week 0 (before intervention) and at week 4 (after intervention). Initials to use:

$\mathrm{ACT}_{0}$ : The value of ACT at week 0 , ie before getting fish oil therapy contains omega-3

$\mathrm{ACT}_{4}$ : The value of ACT at week 4 , ie after getting fish oil therapy containing omega- 3 for 4 weeks (one month)

Lung function: Pulmonary function is measure $21 \mathrm{om}$ the Peak Expiratory Flow (PEF) value. PEF is the maximum ability to expel air in the lungs from the maximum inspiratory state th21ugh the mouth in liters per minute units measured by peak flow meter which is a simple and easy to apply tool ${ }^{\mathbf{1}}$. Pulmonary function is measured 5 times, ie once before the intervention and 3 times During intervention (after 1 week, 2 week, and 3 week intervention), and after intervention. Initials to use:

$\mathrm{PEF}_{0}$ : $\mathrm{PEF}$ value at week 0 , ie before getting fish oil therapy contains omega-3

$\mathrm{PEF}_{1}$ : $\mathrm{PEF}$ value at week 1 st, after getting fish oil therapy containing omega- 3 for 1 week

$\mathrm{PEF}_{2}$ : The value of PEF at week 2 nd, ie after getting fish oil therapy contains omega- 3 for 2 weeks

$\mathrm{PEF}_{3}$ : $\mathrm{PEF}$ value at week $3 \mathrm{rd}$, ie after getting fish oil therapy containing omega- 3 for 3 weeks

$\mathrm{PEF}_{4}$ : PEF value at week 4th, ie after getting fish oil 4 erapy containing omega- 3 for 4 weeks (one month) The population of this study were adult asthma patients (> 18 years) in Surabaya. The sample (subject) of the study were adult asthma patients who were willing to engage in research and meet the requirements, namely: (1) no chronic diseases that can affect respiratory function (such as chronic respiratory illness, heart disease, chronic renal failure, etc.); (2) No smoking or consuming alcohol; and (3) not taking routine asthma medication.

Pulmonary function data and asthma symptoms will be tested the normality of data distribution by using shapiro- wilk test. If $p>0,05$ then it can be concluded that normal distribution data and then proceed with one way anova to know the improvement of lung function and clinical symptoms among respondents Before and after using fish oil.

\section{RESULT}

The research was conducted in 2016-2017 in Suraba 28 . The data used in this study were obtained through the asthma control test (ACT) questionnaire given at the beginning of the first week and the end of the 4th week, peak expiratory flow (PEF) measured weekly for 5 weeks. Based on the data obtained 28 respondents, but 2 people dropped out due to allergy to fish oil and resigned because out of town, then only 26 people who can follow the research.

Characteristics of Respondents

Respondents in this study were grouped by sex, age, and medical history. The number of respondents based on the characteristics of respondents includes age and gender. In the age category, the largest number is the final adolescent (17-25 years old) that is equal to $96.15 \%$ or a number of 25 people and the largest number of female respondents is $73 \%$ or 19 respondents from the total of 26 respondents. The largest number was in the respondents who used a group of agonist beta- 2 short inhalation work of $26.31 \%$ in step 1 (Table 1).

Improvement of Asthma Symptoms with Fish Oil Therapy Containing Omega-3

Characteristics of respondents can be seen in table 2 with the depiction of each category ACT. Most of the symptoms of respondent asthma in three categories, namely: based on activity limitations, frequency of shortness of breath, frequency of asthma drug use, showed no change. But in most asthma symptoms based on asthma symptoms appearing in the evening or morning shows a decrease from the point "not at all" to 16nce up to two times". While asthma symptoms based on the level of control of respondents asthma increased. Based on the total of the overall ACT score, it showed improvement of most respondents with uncontrolled asthma symptoms being partially controlled (Table 2 ).

Normality tests across all ACT categories show all data not normally distributed, except for the total ACT values showing normal distributed data (Table 3 ).

The change in the value of asthma symptoms 39 divided into 3, ie "up" (there was an increase in ACT values $12 \mathrm{rr}$ 4 weeks of fish oil), "fixed" (no change in ACT values after 4 weeks of fish oil) and "dow 12 There was a decrease in ACT value change after being given fish oil for 4 weeks). 
Amelia et al. / Effectiveness of Fish...

Table 7: Changes in PEF Value and Pef Value Differences Test Before and After Omega-3 Fish Oil Therapy.

\begin{tabular}{|c|c|c|c|c|c|c|}
\hline \multirow[t]{3}{*}{ Compared groups } & \multicolumn{3}{|c|}{ Jumlah Responden } & \multicolumn{3}{|c|}{ Uji Perbedaan } \\
\hline & \multicolumn{3}{|c|}{ Changes in PEF Value $(\mathrm{L} / \mathrm{sec})$} & \multirow{2}{*}{$P$ value } & \multirow{2}{*}{ Type of Test Used } & \multirow{2}{*}{ Conclusion } \\
\hline & Up & Constant & Down & & & \\
\hline $\mathrm{PEF}_{0}$ and $\mathrm{PEF}_{1}$ & 20 & 2 & 5 & 0,014 & Friedman Test & $\begin{array}{l}\text { There is a significant } \\
\text { difference }\end{array}$ \\
\hline $\mathrm{PEF}_{0}$ and $\mathrm{PEF}_{2}$ & 21 & 1 & 5 & 0,003 & Friedman Test & $\begin{array}{l}\text { There is a significant } \\
\text { difference }\end{array}$ \\
\hline $\mathrm{PEF}_{0}$ and $\mathrm{PEF}_{3}$ & 20 & 1 & 6 & 0,009 & Friedman Test & $\begin{array}{l}\text { There is a significant } \\
\text { difference }\end{array}$ \\
\hline $\mathrm{PEF}_{0}$ and $\mathrm{PEF}_{4}$ & 24 & 1 & 2 & 0,00 & Friedman Test & $\begin{array}{l}\text { There is a significant } \\
\text { difference }\end{array}$ \\
\hline $\mathrm{PEF}_{1}$ and $\mathrm{PEF}_{2}$ & 20 & 0 & 7 & 0,00 & Anova One Way & $\begin{array}{l}\text { There is a significant } \\
\text { difference }\end{array}$ \\
\hline $\mathrm{PEF}_{2}$ and $\mathrm{PEF}_{3}$ & 16 & 2 & 9 & 0,013 & Anova One Way & $\begin{array}{l}\text { There is a significant } \\
\text { difference }\end{array}$ \\
\hline $\mathrm{PEF}_{3}$ and $\mathrm{PEF}_{4}$ & 21 & 0 & 6 & 0,017 & Anova One Way & $\begin{array}{l}\text { There is a significant } \\
\text { difference }\end{array}$ \\
\hline
\end{tabular}

170.05 ; Ho rejected means there is no significant difference

$\mathrm{P}<0.05 ;$ Ho accepted means there is a significant difference

From table 4 , it can be concluded that most improvements in asthma symptoms are seen only in the asthma level control category, whereas other categories show a fixed value. However, when viewed from the total value of ACT, showed most respondents experienced improvement (Table 4).

Test the difference of asthma symptoms based on ACT value before and after fish oil therapy in table 5 . At th 5 control level of asthma and total ACT value $(\mathrm{P}<0,05)$ it can be concluded that there was significant difference between before and after fish oil therapy containing omega-3 For 4 weeks (Table 5).

Improvement of Lung Function with Omega-3 Fish Oil Therapy

The Difference Test describes the average PEF score obtained once a week after the respondents get a fish oil intervention for 4 weeks. The largest number was in the intervention group at week 4 with an average of 325,00 (Table 6).

Based on the normality test from table 6 indicating that there is data showing abnormal distribution (PEF0 data), the difference test using Friedman Test (Table 7). Based on the difference test, it was concluded that there was a significant improvement on every week (Table 7).

\section{DISCUSSION}

Discussion of Asthma Symptoms Improvement

The results showed changes in ACT values that increased from uncontrolled conditions before treatment were then partially controlled after therapy. This is consistent with existing lib 40 ies that the omega- 3 content of $3 \mathrm{~h}$ oil containing fatty acids has a beneficial effect on chronic inflammatory diseases including chronic obstructive pulmonary disease (COPD), asthma, rheumatoid arthritis, and inflamm 1 tory diseases ${ }^{18}$. Fish oils containing omega 3 comprising EPA and DHA suppress the production of arachidonic acid through the ALOX5 pathway, Arachidonic acid is a substrate for eicosanoid synthesis that produces an inflammatory mediator consisting of
CYS-LT, prostaglandin, and thromboxane. This mediator is involved in the bronchoconstriction process and improves the respiratory tract ri1cus in asthma patients. EPA-enriched fish oil can inhibit the competitive production of LTC4 with arach 1 onic acid that acts as an ALOX5 substrate. EPA can also suppress an allergic response to asthma by inhibiting arachidonic acid that produces leukotrienes. Leukotriene and prostaglandin E2 contribute to the formation of immunoglobulin E (IgE), an antibody that contributes to the occurrence of an allergic response. This is usually increased in patients with asthma ${ }^{13}$. Although the respondents experienced an improvement in ACT scores, there were several factors that could affect the value of ACT, among others:

Gender and age: In table 1, shows the largest number of samples are women than men. In boys have a greater risk in infancy and this risk decreases as they mature 16 /hile in women have a risk of staying in childhood and adulthood. The prevalence of women is higher than men, but the reason for the difference is not clear. However, at birth, men's lung size is smaller than women but as adults are larger. The risk of asthma in boys decreases as they grow older. While in women, the influence of estrogen and progesterone hormones can cause high asthma risk in women during and after puberty ${ }^{20}$. Similarly, the National Center for Health Statistics (NCHS) (2011) ${ }^{21}$, wh 38 says by $\operatorname{sex} 7,2 \%$ of men and $9,7 \%$ of women that the prevalence of women is higher than men. Respondents in this study were mostly in the final adolescent category with age $17-25$ years.

Genetic Factors: There is a relationship between ALOX5's genetic polymorphism and the severity of asthma, whereas ALOX5 is the code of the enzyme that produces leukotriene, which plays the role of the severity of asthm1. Genetic polymorphisms of ALOX5 as well as 5lipoxygenase-activating protein (FLAP) are associated with excessive production of leukotrienes. ALOX5 and FLAP are increased RNA messenger in peripheral blood leukocytes in asthmatics and leukotriene concentrations in 
sputum are greater in asthma patients compared with nonasthma ${ }^{13}$.

Environmental factors (eg trigger exposure): To minimize the influence of environmental factors in this study respondents will always be required to report their activities during fish oil therapy, as factors such as contact with triggers, diet, excessive physical activity, etc. may affect the control of asthma symptoms.

Other therapies used. In the treatment history, most of the samples used inhaled beta- 2 agonist drug inhalation group and all respondents were at step 1 treatment. Asthma treatment is divided into control 25 and reliever. Controller is a daily-used treatment in the long term to keep asthma under clinical control through its anti-inflammatory effects. While reliever is a treatment that is used when necessary and quickly to reduce bronchoconstriction and reduce the acute symptoms that accompany it. In this study, all respondents were at step 1 , which means that none of the respondents used controller asthma medication to maintain their daily asthma control, and all respondents only used asthma medications when experiencing worsening symptoms (reliever). The main choice in this type of reliever is a short action beta- 2 agonist which is generally salbutamol with inhalation route. Inhalation routes are preferred because they are topical, so side effects tend to be smaller and can work directly to the target site in the bronchioles. However, from the data of treatment used by respondents there are some respondents who use corticosteroids (oral or inhalation) and methylxanthine group which is actually an asthma therapy in the controller group ${ }^{1}$.

Discussion of Lung Function Repair

From the research results can be seen that there is an increase in PEF value between the data before and after the patient get therapy. This indicates a potential effect after the respondents are given intervention in the form of fish oil. Improvement of asthma function may be influenced by other uncontrollable factors in research such as psychological (stress) ${ }^{22,23}$, unpredictable weather changes (such as cold or windy air) ${ }^{24,25}$ and daily activities ${ }^{26}$. During the measurement of PEF values, Which can be minimized the activity of respondents because it is done at the same time. The factors that affect the value of PEF but can be controlled in this study include food and drugs consumed. Foods such as fish that contain high protein can cause bias research results. And drugs like asthma medication can increase the value of PEF. However, it can be controlled from the presence of a log book given to the patient to be filled daily containing the activities carried out, drugs and food consumed, and adherence during the consumption of fish oil.

Limitations of Research

Criteria for inclusion of respondents such as heart and kidney history data were not accurately obtained. Because when respondents say that no history of heart and kidney is not supported by the results of checking the doctor first by using electrocardigram (ECG)

In this study using fish oil from a particular brand, which does not rule out the possibility that fish oil with other types can provide effects or not on research related asthma.
Researchers use this type of fish oil because the dose corresponds to the desired dose of fish oil is 1.0 grams. Therefore, respondents feel less comfortable to consume fish oil that is considered quite large because some respondents commented on soft capsule large 24 ugh. Increased prevalence of asthma occurs due to genetic and environmental factors. Asthma is a $24 \mathrm{mplex}$ disease resulting from the interaction between genetic predisposition and environmental factors. Both of these factors not only affect the inflammatory process but also affect the complex and interactive phenotype.

The number of samples in this study were 26 people. Researchers have difficulty in finding a large number of samples to get valid results. Researchers should be able to work with health centers or other health agencies so that the number of samples can be reproduced.

Researchers cannot control racial factors that can affect genetic outcomes. Therefore it is necessary to do further research related to genetic influence (polymorphism of ALOX5) on therapeutic effect of fish oil containing omega-3

\section{CONCLUSION}

Fish oil containing omega- 3 for 4 weeks may decrease asthma symptoms in the asthma control level category and total ACT score. In addition, fish oil can also improve lung function significantly in every week.

\section{ACKNOWLEDGMENTS}

Acknowledgments to DIKTI 2017 and LPPM UBAYA for their support and support in conducting this research.

\section{REFERENCE}

1. The Global Initiative for Asthma (GINA). Update of the GINA Report. Global strategy for asthma management and prevention; 2016 [28 November 2016]. http://www ginasthma.com/.

2. Direktorat Jenderal Pengendalian Penyakit dan Penyehatan Lingkungan. Pedoman Pengendalian Penyakit Asma. Depkes RI: Jakarta. 2009.

3. Direktorat Bina Farmasi Komunitas dan Klinik. Pharmaceutical Care Untuk Penyakit Asma. Depkes RI: Jakarta. 2007.

4. Oemiati R, Sihombing M, Qomariah. Faktor-Faktor yang Berhubungan dengan Penyakit Asma.di Indonesia. Media Litbang Kesehatan. 2010;20(1):41-9.

5. Badan Penelitian dan Pengembangan Kesehatan Departemen Kesehatan Republik Indonesia. 2008. Riset Kesehatan Dasar (RISKESDAS). 2007.

6. Rosenkranz RR. Rosenkranz SK. Neessen KJJ. Dietary factors associated with lifetime asthma or hayfever diagnosis in Australian middle-aged and older adults: a cross-sectional study. Nutrition Journal. 2012;11:84.

7. Aprizayanti. Hubungan Konsumsi Omega 3 Terhadap Tumbuh Kembang Anak Usia 2-3 Tahun di Wilayah Kerja Puskesmas Sebarang Padang Kota Padang Tahun 2011. Universitas Andalas: Padang. 2011.

8. Santoso A, Iriyanti N, S Tri Rahardjo. Penggunaan Pakan Fungsional Mengandung Omega 3, Probiotik dan Isolat Antihistamin $\mathrm{N}_{3}$ Terhadap Kadar Lemak dan 
Kolesterol Kuning Ayam Kampung. Jurnal Ilmiah Peternakan. 2013;1(3):848-855.

9. Thien FCK, S De Luca, RK Woods, MJ Abramson. Dietary marine fatty acids (fish oil) for asthma in adults and children (Review). Cochrane Database Syst Rev. 2010;2.

10. Miyata J, Arita M. Role of omega-3 fatty acids and their metabolites in asthma and allergic diseases. Allergol Int. 2015;64(1):27-34.

11.Arvaniti F, Priftis KN, Panagiotakos DB. Dietary habits and asthma: A review. Allergy Asthma Proc. 2010;31(2):e1-10.

12. McKeever TM, Britton J. Diet and Asthma. Am J Respir Crit Care Med. 2004;170:725-9.

13. Fotenko O, Zeki A, Schuster G, Davis C, Allayee H, Stephensen C, et al. Asthma patients with specific genotypes identified for fish oil treatment trial. California Agriculture. 2011;65(3):112-7.

14.Lorensia A, Wahjuningsih E, Supriadi. Keamanan Penggunaan Aminofilin pada Asma di Rumah Sakit Delta Surya Sidoarjo. Indonesia Journal of Clinical Pharmacy (IJCP). 2012;1(4):154-161.

15.Lorensia A, Ikawati Z, Andayani TM, Maranatha D, Wahjudi M. Analisis Kejadian Leukositosis Pasca Terapi Aminofilin Intravena Dibandingkan dengan Salbutamol Nebulasi pada Pasien Eksaserbasi Asma. Indonesia journal of Clinical Pharmacy (IJCP). 2016;5(3):149-159.

16.Lorensia A, Ikawati Z, Andayani TM, Maranatha D, Wahjudi M. Comparison of Electrolyte Disturbance of Using Intravenous Aminophylline versus Nebulization Salbutamol for Exacerbation Asthma in Surabaya, Indonesia. International Journal of Pharmaceutical and Clinical Research. 2016; 8(4): 221-228.

17.Nelson HS, Weiss ST, Bleecker ER, Yancey SW, Dorinsky PM. The Salmeterol Multicenter Asthma Research Trial: a comparison of usual pharmacotherapy for asthma or usual pharmacotherapy plus Salmeterol. Chest. 2006; 129(1): 15-26

18.Calder PC. Mechanisms of action of (n-3) fatty acids. J Nutr. 2012;142(3):592S-599S.

19. Moamary MSA, Al-Kordi AG, Ghobain MOA, Tamim HM. Utilization and responsiveness of the asthma control test (ACT) at the initiation of therapy for patients with asthma: a randomized controlled trial. BMC Pulmonary Medicine. 2012;12:14.

20.Waldron J. Asthma Care in the Community, John Wiley \& Sons, England. 2007.

21. National Center for Health Statistics (NCHS). Helath, United States, 2011: With Special Feature on Socioeconomic Status and Health. 2011 [28 November 2016]. https://www.cdc.gov/nchs/data/hus/hus11.pdf.

22.Lieshout RJV, MacQueen G. Psychological Factors in Asthma. Allergy Asthma Clin Immunol. 2008;4(1): $12-28$.

23. Kullowatz A, Rosenfield D, Dahme B, Magnussen H, Kanniess F, Ritz T. Stress effects on lung function in asthma are mediated by changes in airway inflammation. Psychosom Med. 2008 May;70(4):46875.

24.Koskela H, Tukiainen H, Kononoff A, Pekkarinen H. Effect of whole-body exposure to cold and wind on lung function in asthmatic patients. Chest. 1994;105(6): 1728-31.

25. Watanabe M, Noma H, Kurai J, Hantan D, Burioka N, Nakamoto S, Sano H, Taniguchi J, Shimizu E. Association between Outdoor Fungal Concentrations during Winter and Pulmonary Function in Children with and without Asthma. Int J Environ Res Public Health. 2016;13(5):452.

26.Ritz T, Rosenfield D, Steptoe A. Physical Activity, Lung Function, and Shortness of Breath in the Daily Life of Individuals with Asthma. CHEST 2010; 138(4):913-918. 
Effectiveness_of_Fish_Oil_Containing_Omega.pdf

ORIGINALITY REPORT

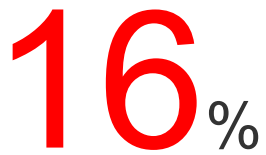

SIMILARITY INDEX
$10 \%$

INTERNET SOURCES
$8 \%$

PUBLICATIONS
$11 \%$

STUDENT PAPERS

PRIMARY SOURCES

1 calag.ucanr.edu

Internet Source

2 id.123dok.com

Internet Source

3 getasthmahelp.org

Internet Source

4 docobook.com

Internet Source

5 Submitted to Universiti Sains Malaysia

Student Paper

6 Submitted to Padjadjaran University

Student Paper

7 impactfactor.org

Internet Source

8 www.tandfonline.com

Internet Source 
11 Submitted to Queen Mary and Westfield College

Student Paper

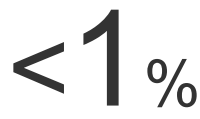

12 Harats, D.. "Fish oil ingestion in smokers and nonsmokers enhances peroxidation of plasma lipoproteins", Atherosclerosis, 199110

Publication

13 sastra.um.ac.id

Internet Source

14 Mohamed A. El-Nabarawi, Ehab R. Bendas, Randa Tag A. El Rehem, Mohammed Y.S.

Abary. "Transdermal drug delivery of paroxetine

through lipid-vesicular formulation to augment

its bioavailability", International Journal of

Pharmaceutics, 2013

Publication

15 Submitted to iGroup

Student Paper

16 www.ginasthma.org

Internet Source

17 Submitted to International School Manila

Student Paper

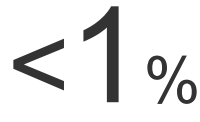


20 Karen Rance. "Helping patients attain and maintain asthma control: reviewing the role of the nurse practitioner", Journal of Multidisciplinary Healthcare, 08/2011 Publication

21 Submitted to Bahrain School Student Paper

22 Kenji Baba. "Age-Dependent Deterioration of Peak Inspiratory Flow with Two Kinds of Dry Powder Corticosteroid Inhalers (Diskus ${ }^{\mathrm{R}}$ and Turbuhaler $^{R}$ ) and Relationships with Asthma Control", Journal of Aerosol Medicine and Pulmonary Drug Delivery, 11/02/2011

\section{Publication}

23 www.taipanonline.com

Internet Source

24 Submitted to London School of Hygiene and Tropical Medicine 
28 bmcpulmmed.biomedcentral.com

29 tel.archives-ouvertes.fr

30 Muhammad Hilmi Afthoni, Mariana Wahjudi,

Bambang Kuswandi. "27 Afthoni et al. Novel

Scanometric Assay for Charantin in Bitter Melon

( Momordica charantia ) Extract Based on

Immobilized Silver Nitrate and Methylene Blue

as Colorimetric Paper", Journal of Food

Chemistry \& Nanotechnology, 2018

Publication

31

www.indonesiajournalchest.com

Internet Source

B. B. Koolen, M. W. H. Pijnenburg, H. J. L.

Brackel, A. M. Landstra et al. "Comparing

Global Initiative for Asthma (GINA) criteria with

the Childhood Asthma Control Test (C-ACT)

and Asthma Control Test (ACT)", European

Respiratory Journal, 2011

Publication

pastel.archives-ouvertes.fr 
34 Yuli Kurniawati, Mutia Devi, Kemas Yakub,

Khairani Affandi, Allin Marlina. "Correlation of

serum lipid profile with leptin levels of skin tags

patients", Journal of Physics: Conference

Series, 2019

Publication

35 hdl.handle.net

Internet Source

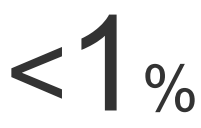

36 Submitted to University of Greenwich

Student Paper

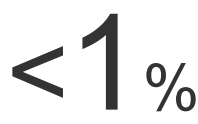

37 www.nice.org.uk

Internet Source

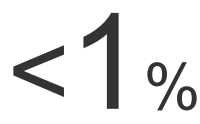

38 Huriletemuer, Shirong Wen, Chunyu Zhang,

Shigang Zhao, Guangming Niu, Binbin Wang,

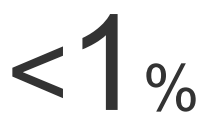

Xu Ma, Desheng Wang. "An epidemiological

study of Alzheimer's disease in elderly

Mongolian and Han populations living in rural

areas of Inner Mongolia", Aging Clinical and

Experimental Research, 2013

Publication

39

Peter Singer. "Blood Pressure-Lowering Effect

of ?3 Polyunsaturated Fatty Acids in Clinical

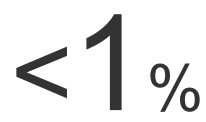

Studies", S. Karger AG, 1991

Publication

S. Tricon. "Nutrition and allergic disease",

Clinical \& Experimental Allergy Reviews, 9/2006 
41 "Spoken sessions", Thorax, 2002 